
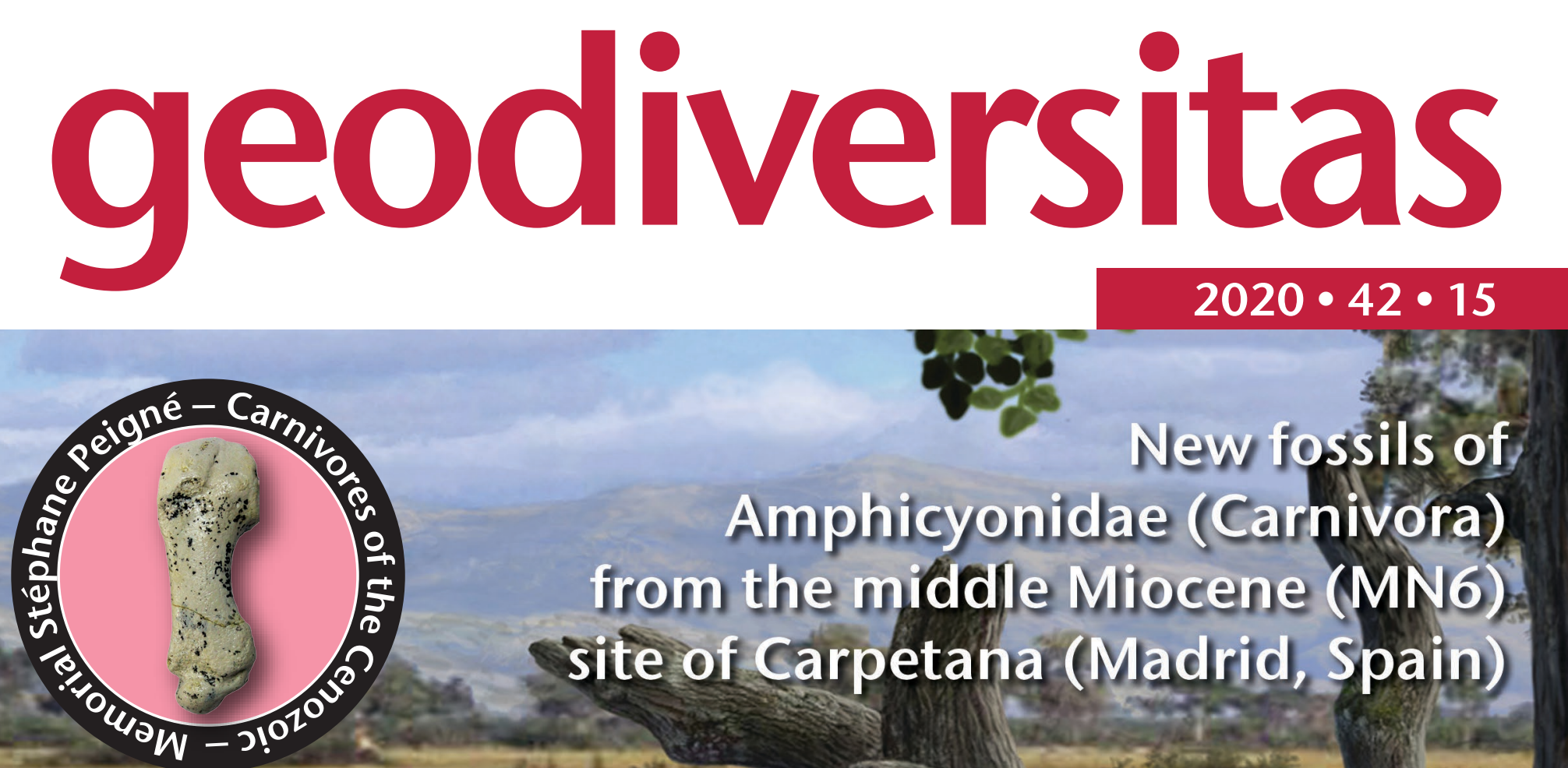

New fossils of Amphicyonidae (Carnivora) from the midalle Mliocene (MN6) site of Carpetana (Madrid, Spain)

Gema SILICEO, Jorge MORALES, Mauricio ANTÓN \& Manuel J. SALESA
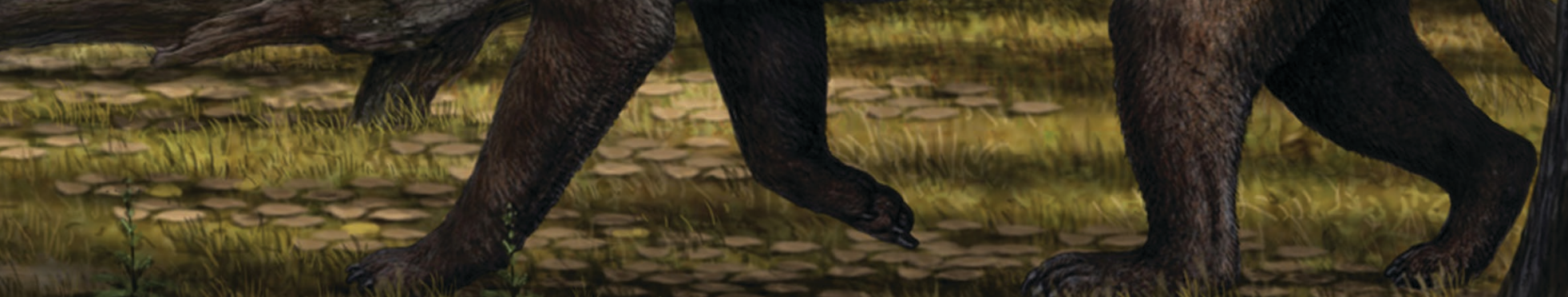
DiRECTEUR de LA PUBLICATION / PUBLICATION DIRECTOR: Bruno David, Président du Muséum national d'Histoire naturelle

RÉdACTEUR EN CHEF / EDITOR-IN-CHIEF: Didier Merle

ASSISTANT DE RÉDACTION / ASSISTANT EDITOR: Emmanuel Côtez (geodiv@mnhn.fr)

Mise en PAge / PAGE LAyout: Audrina Neveu, Emmanuel Côtez

COMITÉ SCIENTIFIQUE / SCIENTIFIC BOARD:

Christine Argot (Muséum national d'Histoire naturelle, Paris)

Beatrix Azanza (Museo Nacional de Ciencias Naturales, Madrid)

Raymond L. Bernor (Howard University, Washington DC)

Alain Blieck (chercheur CNRS retraité, Haubourdin)

Henning Blom (Uppsala University)

Jean Broutin (Sorbonne Université, Paris, retraité)

Gaël Clément (Muséum national d'Histoire naturelle, Paris)

Ted Daeschler (Academy of Natural Sciences, Philadelphie)

Bruno David (Muséum national d'Histoire naturelle, Paris)

Gregory D. Edgecombe (The Natural History Museum, Londres)

Ursula Göhlich (Natural History Museum Vienna)

Jin Meng (American Museum of Natural History, New York)

Brigitte Meyer-Berthaud (CIRAD, Montpellier)

Zhu Min (Chinese Academy of Sciences, Pékin)

Isabelle Rouget (Muséum national d'Histoire naturelle, Paris)

Sevket Sen (Muséum national d'Histoire naturelle, Paris, retraité)

Stanislav Štamberg (Museum of Eastern Bohemia, Hradec Králové)

Paul Taylor (The Natural History Museum, Londres, retraité)

COUVERTURE / COVER:

Reconstruction of the life appearance of Megamphicyon giganteus (Schinz, 1825) in the Miocene habitat of the Carpetana fossil site (artwork by M. Antón).

Geodiversitas est indexé dans / Geodiversitas is indexed in:

- Science Citation Index Expanded (SciSearch $\left.{ }^{\circledR}\right)$

- ISI Alerting Services ${ }^{\circledR}$

- Current Contents ${ }^{\circledR}$ / Physical, Chemical, and Earth Sciences ${ }^{\circledR}$

- Scopus ${ }^{\circledR}$

Geodiversitas est distribué en version électronique par / Geodiversitas is distributed electronically by:

- BioOne ${ }^{\circledR}$ (http://www.bioone.org)

Les articles ainsi que les nouveautés nomenclaturales publiés dans Geodiversitas sont référencés par /

Articles and nomenclatural novelties published in Geodiversitas are referenced by:

- ZooBank ${ }^{\circledR}$ (http://zoobank.org)

Geodiversitas est une revue en flux continu publiée par les Publications scientifiques du Muséum, Paris Geodiversitas is a fast track journal published by the Museum Science Press, Paris

Les Publications scientifiques du Muséum publient aussi / The Museum Science Press also publish:

Adansonia, Zoosystema, Anthropozoologica, European Journal of Taxonomy, Naturae, Cryptogamie sous-sections Algologie, Bryologie, Mycologie.

Diffusion - Publications scientifiques Muséum national d'Histoire naturelle

CP 41 - 57 rue Cuvier F-75231 Paris cedex 05 (France)

Tél. : 33 (0)1407948 05 / Fax: 33 (0)14079 3840

diff.pub@mnhn.fr / http://sciencepress.mnhn.fr

(C) Publications scientifiques du Muséum national d'Histoire naturelle, Paris, 2020

ISSN (imprimé / print): 1280-9659/ ISSN (électronique / electronic): 1638-9395 


\title{
New fossils of Amphicyonidae (Carnivora) from the middle Miocene (MN6) site of Carpetana (Madrid, Spain)
}

\author{
Gema SILICEO \\ Jorge MORALES \\ Mauricio ANTÓN \\ Manuel J. SALESA \\ Departamento de Paleobiología, Museo Nacional de Ciencias Naturales-CSIC. \\ C/José Gutiérrez Abascal, 2. 28006 Madrid (Spain) \\ siliceo@mncn.csic.es (corresponding author) \\ mcnm166@mncn.csic.es \\ mauricioanton24@gmail.com \\ msalesa@mncn.csic.es
}

Submitted on 31 January 2019 | accepted on 19 November 2019 | published on 18 June 2020

KEY WORDS

Carnivora, Megamphicyon,

Middle Miocene, Locomotor adaptations.

MOTS CLÉS Carnivora, Megamphicyon, Espagne,

Miocène moyen, adaptations locomotrices.
urn:Isid:zoobank.org:pub:83F7A817-E9BA-4F3D-83DA-B86B9512B984

Siliceo G., Morales J., Antón M. \& Salesa M. J. 2020. - New fossils of Amphicyonidae (Carnivora) from the middle Miocene (MN6) site of Carpetana (Madrid, Spain), in Bonis L. de \& Werdelin L. (eds), Memorial to Stéphane Peigné: Carnivores (Hyaenodonta and Carnivora) of the Cenozoic. Geodiversitas 42 (15): 223-238. https://doi.org/10.5252/geodiversitas2020v42a15. http://geodiversitas.com/42/15

\section{ABSTRACT}

Herein, we present a study of an interesting sample of fossils of the giant amphicyonid Megamphicyon giganteus (Schinz, 1825) from the Spanish middle Miocene (MN6) site of Carpetana (Madrid city), obtained during public works for the Madrid underground in 2008. Although the dentition of this species is known from other sites, the postcranial bones are very poorly known, and the new material provides new data on the locomotor adaptations of this spectacular predator, and allows an estimation of its body mass, which would be around $600 \mathrm{~kg}$. Surprisingly, despite this giant size, the morphology of both femur and tibia shows that this animal exhibited higher cursorial capacity than large extant carnivorans, such as bears, which together with a high degree of pronation/supination movement of the forearm, reveals adaptations of $M$. giganteus to occupy the niche of active top predator in middle Miocene ecosystems.

\section{RÉSUMÉ}

Nouveaux fossiles d'Amphicyonidae (Carnivora) du Miocène moyen (MNG) de Carpetana (Madrid, Espagne). Nous présentons ici l'étude d'un échantillon intéressant de fossiles de l'amphicyonidé géant Megamphicyon giganteus (Schinz, 1825) du gisement espagnol du Miocène moyen (MN6) de Carpetana (Madrid), obtenus lors de travaux publics dans le métro de la ville en 2008. Bien que la dentition de cette espèce soit connue sur d'autres sites, les os postcrâniens sont très mal connus, et le nouveau matériel fournit de nouvelles données sur les adaptations locomotrices de ce spectaculaire prédateur, et permet une estimation de sa masse corporelle, qui avoisinerait $600 \mathrm{~kg}$. Étonnamment, malgré cette taille gigantesque, la morphologie du fémur et du tibia montre que cet animal présentait des capacités de coureur plus élevées que les grands carnivores existants, tels que les ours, ce qui, outre un degré élevé de mouvements de pronation/supination sur l'avant-bras, révèle les adaptations de $M$. giganteus à occuper le créneau des principaux prédateurs actifs des écosystèmes du Miocène moyen. 


\section{INTRODUCTION}

The Amphicyonidae is a family of arctoid carnivorans present in the mammalian faunas of North America, Africa and Eurasia from the late Eocene to the late Miocene (Viranta 1996; Hunt 1998, 2002; Peigné et al. 2008; Werdelin \& Peigné 2010). The group had its greatest diversity during the Oligocene and early-middle Miocene, decreasing in the late Miocene, with very few taxa surviving into the Vallesian and latest Turolian (Beaumont 1984; Hunt 1998; Werdelin \& Simpson 2009). The body mass of Amphicyonidae varies from few kilograms in the smallest species, up to $550 \mathrm{~kg}$ in the giant forms (Viranta 1996; Hunt 2001, 2003; Sorkin 2006; Figueirido et al. 2011), showing one of the widest size ranges among Carnivora. The dentition of amphicyonids was relatively homogeneous, with small mesial premolars, large carnassials, and robust postcarnassial teeth, suggesting a diet ranging from omnivorous to relatively hypercarnivorous (Viranta 1996; Hunt 1998; Peigné et al. 2008). In general, amphicyonids have more generalized postcranial skeletons than those of extant large carnivorans, and some species probably exhibited an ambulatory locomotion with climbing abilities, in some ways resembling modern ursids, whereas other species developed cursorial adaptations (Ginsburg 1961a; Viranta 1996; Hunt 1998, 2002, 2003, 2009, 2011; Sorkin 2006; Argot 2010).

Among middle Miocene European Amphicyonidae, the genus Amphicyon is the best represented in the fossil faunal assemblages, with $A$. major Blainville, 1841 from Sansan being a reference for knowledge of the general anatomy of this group of carnivorans (Ginsburg 1961a, 1999; Argot 2010). Amphicyon major was a very large carnivoran, probably a top predator in the mammalian communities from MN4 to MN8, but there was another, even larger species, A. giganteus Schinz, 1825, which was present in faunas from MN4 to MN6 (Ginsburg \& Antunes 1968; Viranta 1996; Fraile et al. 1997; Ginsburg 1961a, 1999; Peigné et al. 2006; Argot 2010), thus overlapping the form from Sansan in stratigraphic distribution. Both carnivorans were large predators, and their presence in the same area is improbable, as they would compete for the same resources. In extant ecosystems, when two large carnivorans share habitat, that is because a spatial or ecological segregation exists, which can be explained by differences in body size, activity patterns, habitat choice, or degree of sociality (Linnell \& Strand 2000; Hayward et al. 2006; McDonald et al. 2008); this segregation prevents recurrent aggressive encounters between them, which very likely would produce severe wounds or even the death of one or both of them. Thus, the overlap in stratigraphic distribution of these two large amphicyonids suggests differences in habitat requirements or locomotor/ethological adaptations; unfortunately, few postcranial bones of $A$. giganteus are known, which has hindered a deep functional comparison between the postcranial anatomy of this species and that of $A$. major.

In 1965, Kuss proposed the genus Megamphicyon Kuss, 1965 to separate $A$. major from A. giganteus, based on its larger size and some dental features, such as a very wide and slightly pentagonal M1, and a relatively narrow M2. This proposal was followed with moderate enthusiasm by later authors, and it was more often cited as a subgenus within Amphicyon, rather than as a separate genus (Ginsburg 2001, 2002; Gagnaison 2013, 2017). In the present work we study new dental and postcranial remains of this giant amphicyonid from the Middle Miocene (MN6) site of Carpetana (Madrid, Spain), discovered in 2008, which has yielded an interesting fossil association with an abundance of equids (Anchitherium) and suids (Conohyus) (Pickford 2013). After a detailed comparison of the amphicyonid fossils from this site with other European material of the type species of the genus Amphicyon, A. major, we find enough morphological differences to support a generic separation of the material from Amphicyon, and thus we include the new material in Megamphicyon giganteus (Schinz, 1825).

\section{MATERIAL AND METHODS}

The fossils of Megamphicyon giganteus from Carpetana described here are housed in the collections of the Museo Nacional de Ciencias Naturales-CSIC (Madrid, Spain), and were found in 2008, during public works carried out in the subway station of Carpetana, in the city of Madrid, when emptying an area destined for the installation of an elevator.

Some of the fossils of $M$. giganteus from Carpetana are broken, whereas others are almost complete, but they show erosion and dissolution of some parts, which has led to the loss of several structures of anatomical interest. Nevertheless, some of the bones, such as the tibia, provide interesting data on the locomotor adaptations of this giant amphicyonid.

Comparisons with extant carnivorans were made using the collections of the Museo Anatómico de la Universidad de Valladolid (Spain) (MAV) and Museo Nacional de Ciencias Naturales-CSIC (Madrid, Spain) (MNCN), which provided complete skeletons of the ursid Ursus americanus Pallas, 1780 (MAV-259), the felines Panthera leo (Linnaeus, 1758) (MAV-2313, MAV-3046 and MAV-276) and Acinonyx jubatus (Schreber, 1775) (MNCN-3438), and the canid Canis lupus Linnaeus, 1758 (MNCN-16118 and MNCN-16150). The material of Amphicyon major from the locality of Sansan (MN 6, France) was studied in the collections of the Muséum national d'Histoire naturelle (Paris, France). The anatomical descriptions follow the terminology used by Barone (2010a, b), Evans (1993), and the ICVGAN (2017). The measurements were taken with a digital caliper.

$\begin{array}{ll}\text { ABBREVIATIONS } \\ \mathrm{L} & \text { lumbar vertebra; } \\ \mathrm{l} & \text { length; } \\ \mathrm{Mc} & \text { metacarpal; } \\ \mathrm{Mt} & \text { metatarsal; } \\ \mathrm{M} & \text { upper molar; } \\ \mathrm{m} & \text { lower molar; } \\ \mathrm{P} & \text { upper premolar; } \\ \mathrm{p} & \text { lower premolar; } \\ \mathrm{T} & \text { thoracic vertebra; } \\ \mathrm{w} & \text { width. }\end{array}$


B

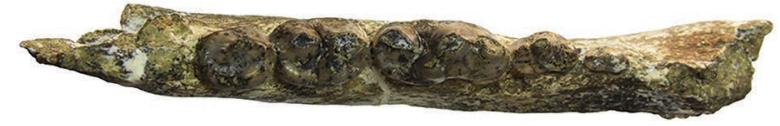

A

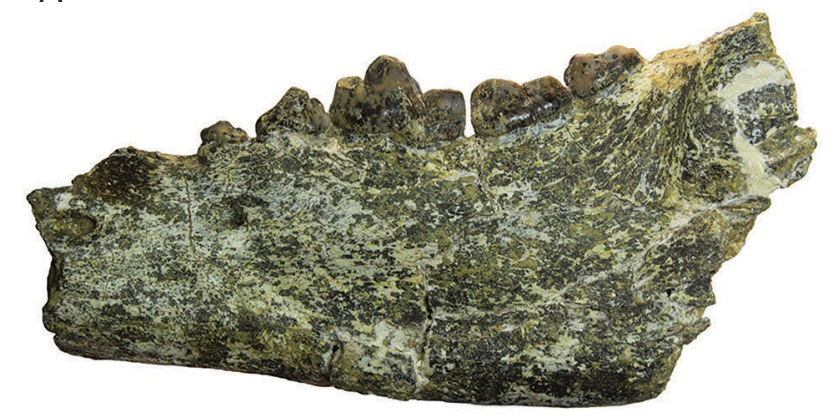

C

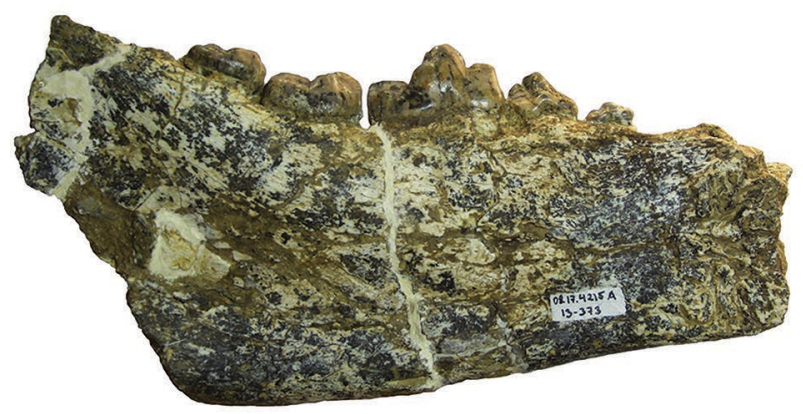

FIG. 1. - Fragment of the left hemimandible 08.17.4215 A 13-373 of Megamphicyon giganteus (Schinz, 1825) from Carpetana: A, buccal view; B, occlusal view; C, lingual view. Scale bar: $5 \mathrm{~cm}$.

\section{SYSTEMATIC PALAEONTOLOGY}

Order CARNIVORA Bowdich, 1821

Suborder CANIFORMIA Kretzoi, 1943

Family AMPHICYONIDAE Haeckel, 1866

Subfamily AMPHiCYONINAE Haeckel, 1866

Genus Megamphicyon Kuss, 1965

\section{Megamphicyon giganteus (Schinz, 1825)}

DiagNOSIS. - Amphicyonid similar to Amphicyon major, but with the following differences: much larger size; the M1 is much more mesiodistally elongated, with very high buccal cusps, and with the mesial and distal margins inflated at the level of the paraconule and metaconule; M2 with lower buccal tubercles, protocone formed of a single ridge, connected to the paraconule; vertical or absent metaconule, generally not connected to the protocone; lower canine shorter and stout; $\mathrm{m} 1$ with curved walls and the lingual part of the talonid narrower and elongated; $\mathrm{m} 2$ high, with strong protoconid, and metaconid strongly dominating a well-formed talonid, presence of a vestigial paraconid; very long m3 (Ginsburg \& Antunes 1968).

Holotype. - Left M1 from the site of Avaray (Loir-et-Cher), figured by Cuvier (1824: pl. 193, fig. 20), Mayet (1908: fig. 24 , 68, pl. VII) and Kuss (1965: fig. 42), housed at the collections of the Musée d'Orléans.

MATERIAL EXAMINED. - The list of fossils of $M$. giganteus studied here is as follows (catalogue numbers in parentheses): left hemimandible preserving the dental series $\mathrm{p} 3-\mathrm{m} 3$ (08.17.4215 A 13-373); twelfth or thirteenth thoracic vertebra (T12/T13) (08.17.11003A), first lumbar vertebra (L1) (08.17.11003C), Sacrum (08.17.10203FC), left ulna (08.17.10199FC), right radius (08.17.10200FC-1), fragment of proximal half of left radius (08.17.10201AFC). Left Mc V (08.17.20989FC), distal fragment of right femur (08.17.10271DFC), left tibia (08.17.10270-6A-FC), and left Mt IV (08.17.99728-538).

\section{DESCRIPTION OF HEMIMANDIBLE AND LOWER DENTITION} 08.17.4215 A 13-373: left hemimandible preserving the dental series $\mathrm{p} 3-\mathrm{m} 3$, as well as two possible alveoli for $\mathrm{p} 1$ and $\mathrm{p} 2$ (Fig. 1A-C); both the mandibular ramus and symphysis are broken. There is a short diastema between p3 and p4, and a longer one mesial to p3. The preserved mesial border corresponds to the distal surface of the lower canine alveolus. On the labial face there is a well-developed mandibular foramen located at the level of the diastema separating the lower canine and p1; a second foramen is located just below the p3. The mandibular symphysis shows a very rough lingual surface, with a marked genial tuberosity; it is distally developed until the diastema of p2-p3. The p3 has a relatively small crown, although it has a long talonid showing a small cuspid, somewhat higher and more marked than the rounded mesial accessory cuspid. The p4 is relatively large, mesially thickened, and with a high and large distal accessory cuspid; its basal cingulum is very reduced, and there is almost no trace of a talonid. The $\mathrm{m} 1$ is buccolingually flattened, with a short paraconid in comparison to the protoconid, virtually without a lingual valley separating the two cuspids; the metaconid is very close to the distal margin of the protoconid; the talonid is almost completely occupied by a large hypoconid, lingually separated from a very reduced entoconid. The $\mathrm{m} 2$ is relatively large, with a high and straight protoconid occupying half of the tooth; there is no paraconid, and the metaconid is distally displaced, as in the $\mathrm{m} 1$, although it is relatively larger; the mesial trigonid valley is very reduced, and thus the mesiolingual wall is only composed of the protoconid and the metaconid, unlike most Amphicyonidae, which have a mesiolingual wall composed of the metaconid and a very reduced paraconid; the buccal wall of the protoconid is quite vertical, without buccal expansion; the talonid is large and, similarly to $\mathrm{m} 1$, it is mostly occupied by the hypoconid, although the entoconid is more developed than that of the latter tooth. The $\mathrm{m} 3$ is also relatively well developed; the trigonid is wide, with the protoconid and metaconid being of similar size and located the same distance from the mesial border of the tooth; the distal cristid of both the protoconid and the metaconid extends distally until contacting the hypoconid and talonid, respectively, delimiting a wide and shallow central valley. 
TABLE 1. - Measurements of the lower dentition of M. giganteus (Schinz, 1825) and A. major Blainville, 1841 showing the difference in size. Measurements of A. major taken from Peigné (2012).

\begin{tabular}{|c|c|c|c|c|c|c|c|c|c|}
\hline & & p4l & p4w & m1l & m1w & m2I & m2w & m3l & m3w \\
\hline M. giganteus Carpetana & & 21.8 & 13.3 & 40 & 19.1 & 30.1 & 20.5 & 23.4 & 18.6 \\
\hline A. major & $\begin{array}{l}\text { mean } \\
\min \\
\max \\
\mathrm{n}\end{array}$ & $\begin{array}{l}18.03 \\
16.5 \\
19 \\
3\end{array}$ & $\begin{array}{l}9.56 \\
8.9 \\
10.1 \\
4\end{array}$ & $\begin{array}{l}33.59 \\
30.35 \\
36.9 \\
6\end{array}$ & $\begin{array}{l}15.74 \\
14 \\
17.3 \\
7\end{array}$ & $\begin{array}{l}22.75 \\
21.35 \\
25.5 \\
3\end{array}$ & $\begin{array}{l}16.56 \\
16 \\
17.7 \\
3\end{array}$ & $\begin{array}{l}18.7 \\
17.1 \\
20.3 \\
2\end{array}$ & $\begin{array}{l}15.1 \\
13.9 \\
16.3 \\
2\end{array}$ \\
\hline
\end{tabular}

\section{Comparisons}

In overall view, the teeth of Amphicyon major from Sansan are smaller than those from Carpetana, both samples showing a set of morphological differences (Table 1 ). The $\mathrm{p} 4$ of $A$. major is relatively smaller and lower than that from Carpetana, with a narrower mesial part. The $\mathrm{m} 1$ of $A$. major is more primitive, with a well-developed lingual valley separating the paraconid from the protoconid, a relatively large metaconid, and a large and high hypoconid that only occupies the buccal half of the talonid. Concerning the $\mathrm{m} 2$, the differences can be related to a greater degree of specialization of the form from Carpetana: $A$. major retains, as primitive features, a lingual wall composed of the metaconid and paraconid, a mesial valley in the trigonid, a marked buccal expansion of the protoconid wall, and a relatively wider talonid, with a relatively smaller hypoconid.

Although there is no upper dentition in the Carpetana sample, the locality of Arroyo del Val (Zaragoza), of similar age, has yielded a nice sample of P4, M1 and M2 of Megamphicyon giganteus (Peigné et al. 2006) that can be used for comparison with the sample of $A$. major from Sansan. The P4 from Arroyo del Val shows a more developed parastyle than those from Sansan and a wider, lower and more distally located protocone; the M1 has a more developed buccal wall, larger and lower paracone and metacone, and a more centrally located protocone; and the M2 is buccolingually wider, and the protocone is more centrally located.

\section{DESCRIPTION OF POSTCRANIAL ELEMENTS Vertebrae}

Although several vertebral fragments were found in Carpetana, only two vertebrae can be certainly assigned to an amphicyonid. These two vertebrae have most of the processes broken, although the preserved morphology indicates that one of them (08.17.11003A) is probably one of the last thoracic vertebrae (T12 or T13) (Fig. 2F-I), whereas the other one (08.17.11003C) can be identified as the first lumbar vertebra (L1) (Fig. 2D-E). The size and morphology of these vertebrae fit well with both the relative size and morphology of other known amphicyonid vertebrae, such as $A$. major or Magericyon anceps Peigné, Salesa, Antón \& Morales, 2008 (Ginsburg 1961a; Argot 2010; Siliceo et al. 2019). The thoracic vertebra of the amphicyonid from Carpetana shows some of the distinctive features of the last thoracic vertebrae (T12 and T13), which typically exhibit a similar morphology to that of the lumbar series. Thus, the right cranial articular process is medially oriented, with a slightly concave surface, and is located at the base of a dorsally developed mammillary process. The two caudal articular processes are also preserved: they are laterally oriented and show slightly convex surfaces. This thoracic vertebra $(08.17 .11003 \mathrm{~A})$ shows a large fovea costalis cranialis on its right side (the left one is barely visible because of the poor preservation) for the articulation with the head of the rib, but lacks both the transverse processes and the fovea costalis transversi. The other vertebra from Carpetana (08.17.11003C) shows a poorer preservation than the thoracic one, but it can be identified as the L1 based on the presence of the basal portion of the costal processes; one of these processes preserves its caudolateral border, suggesting a small size for this costal process, and thus indicating that this vertebra is probably $\mathrm{L} 1$, or, less probably, L2. One of the caudal articular processes is also preserved, showing a lateroventral orientation of its articular surface. The base of a strong left accessory process is also visible, showing the typical morphology of the L1.

\section{Sacrum}

A complete amphicyonid sacrum from Carpetana is preserved (08.17.10203FC) (Fig. 2A-C). It is composed of three fused sacral vertebrae, like that of most extant carnivorans, except ursids, which have a sacrum that is usually composed of five vertebrae. The sacrum from Carpetana is sub-rectangular, with its maximum mediolateral width at the level of the cranial margin. The three sacral vertebral bodies are of similar size, but the first sacral vertebra is markedly wider. Only the last spinous process is present. It is well-developed and shows a thickened dorsal tip. The cranial articular processes are laterocranially projected and their articular surfaces are dorsomedially oriented. The caudal articular processes are laterally oriented, their articular surfaces being markedly convex. The sacral wing, formed by the transverse processes of the first sacral vertebra, is ventrally projected, has thickened borders, and shows a rough lateral surface for the articulation with the os coxae. The lateral sacral crest (the fused transverse processes of the second and third sacral vertebrae) is not laterally expanded; it has a thick and rough border, but at least one of its borders seems to be broken, so the actual expansion of this crest is not easy to assess. The caudal extremes of the lateral sacral crest (transverse processes of the last sacral vertebra) are broken. The intermediate sacral crest is rough, with the tuberosities of the second sacral vertebrae being the most marked ones. Along these crests, several fascicles of the 
A

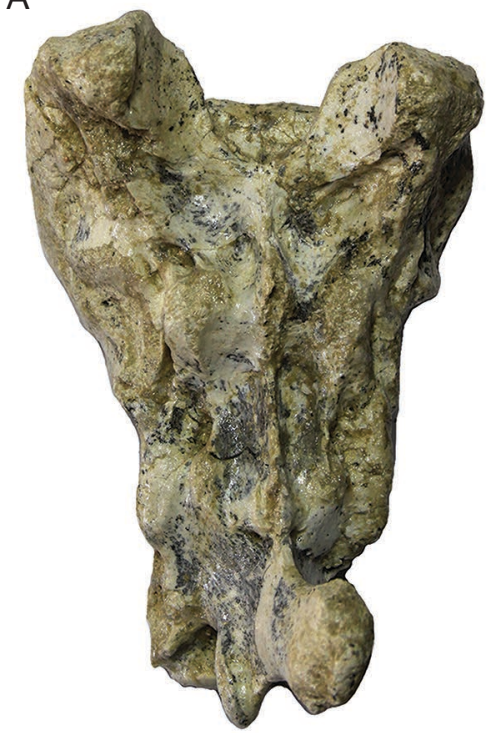

B

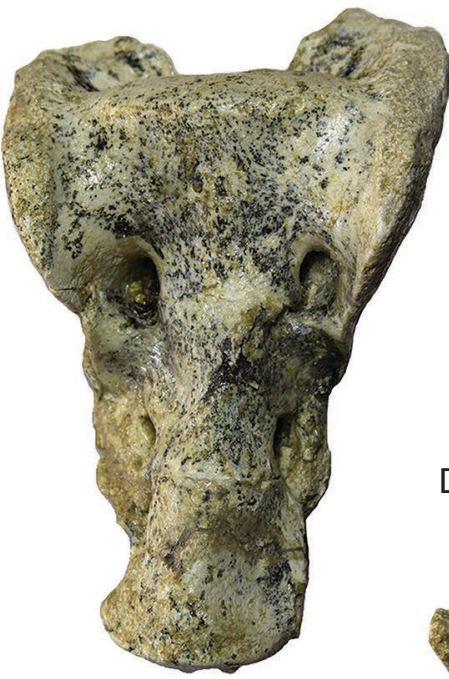

C

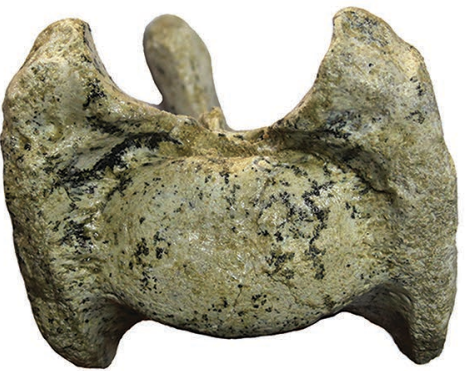

D

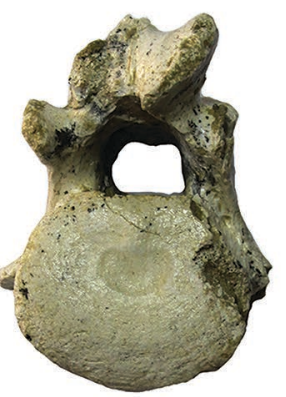

E
F

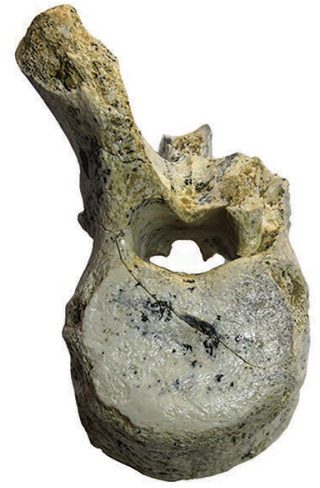

G

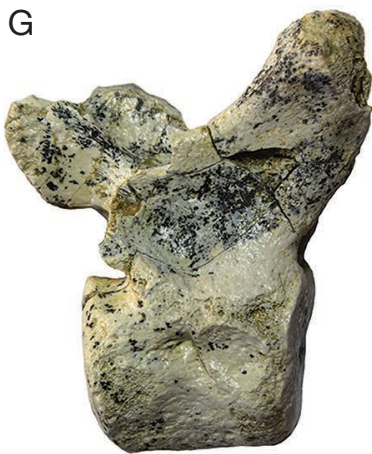

$\mathrm{H}$

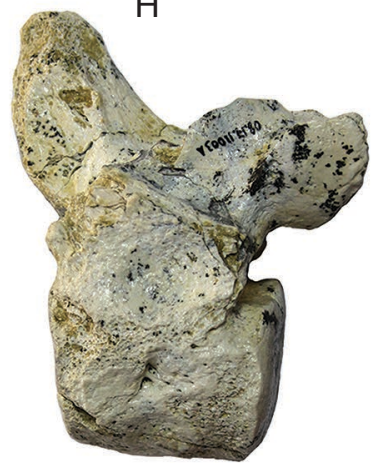

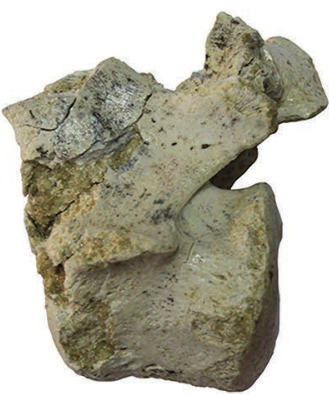

I

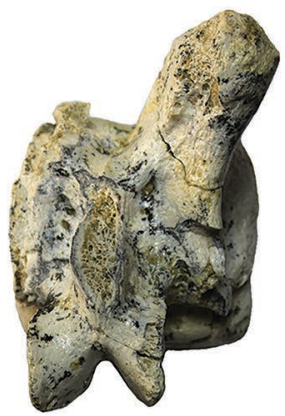

FIG. 2. - Vertebrae and sacrum of Megamphicyon giganteus (Schinz, 1825) from Carpetana. Sacrum 08.17.10203FC: A, dorsal view, B, ventral view; C, cranial view. First lumbar vertebra (L1) 08.17.11003C: D, caudal view; E, left view. Twelfth or thirteenth thoracic vertebra (T12/T13) 08.17.11003A: F, cranial view; G, right view; H, left view; I, dorsal view. Scale bar: $5 \mathrm{~cm}$.

m. sacrocaudalis dorsalis lateralis and mm. intertransversarii dorsales caudae are attached, as well as the strong lig. sacrotuberalis, which ends on the ischiatic tuberosity. On the ventral side of the sacrum (pelvian facies), the lines between the sacral vertebrae (= lineae transversae) are present. Along this ventral surface, the caudal muscles, $m$. sacrocaudalis ventralis lateralis and $m$. sacrocaudalis ventralis medialis are attached.

The overall morphology of the sacrum of the amphicyonid from Carpetana shows some similarities with those of large felids such as Panthera leo, as it is composed of three vertebrae and lacks the marked distal narrowing shown by canids. Nevertheless, it differs from that of felids in some aspects: the spinous processes are stronger in the amphicyonid, they have thickened dorsal tips, and their overall shape is more rectangular. The morphology of $08.17 .10203 \mathrm{FC}$ suggests that the amphicyonid from Carpetana probably had a long and muscular tail, a typical feature of the family Amphicyonidae (Argot 2010; Siliceo et al. 2019). For example, the lack of reduction in the size of the sacral vertebrae indicates a relatively high number of caudal vertebrae, whereas the presence of strong spinous processes in the sacrum is indicative of strong and well-developed caudal muscles.

\section{Radius}

There are two radii of $M$. giganteus from Carpetana; one of them is almost complete (08.17.10200FC-1) (Fig. 3A, B), whereas the other one is a fragment of the proximal half that only preserves a small part of the proximal articular surface (08.17.10201AFC). Although the proximal and distal epiphyses are damaged in both specimens, they still preserve some interesting features. In 08.17.10200FC-1, the most complete 
A

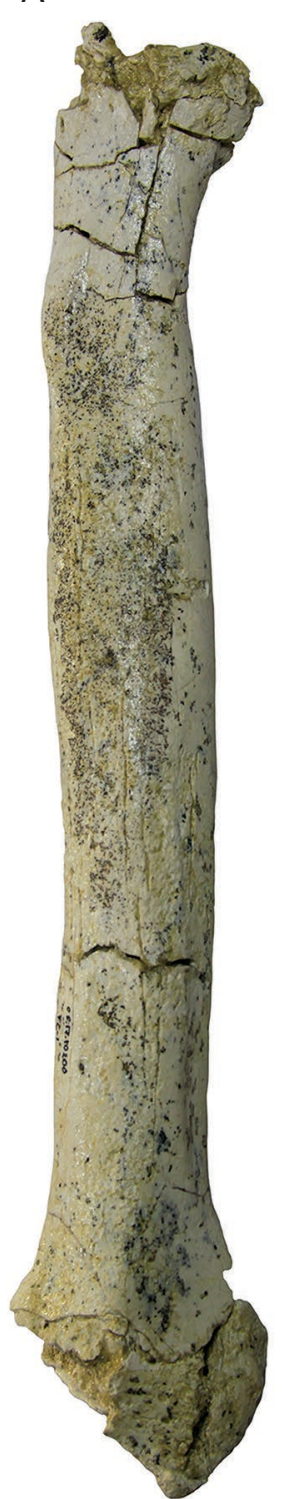

C

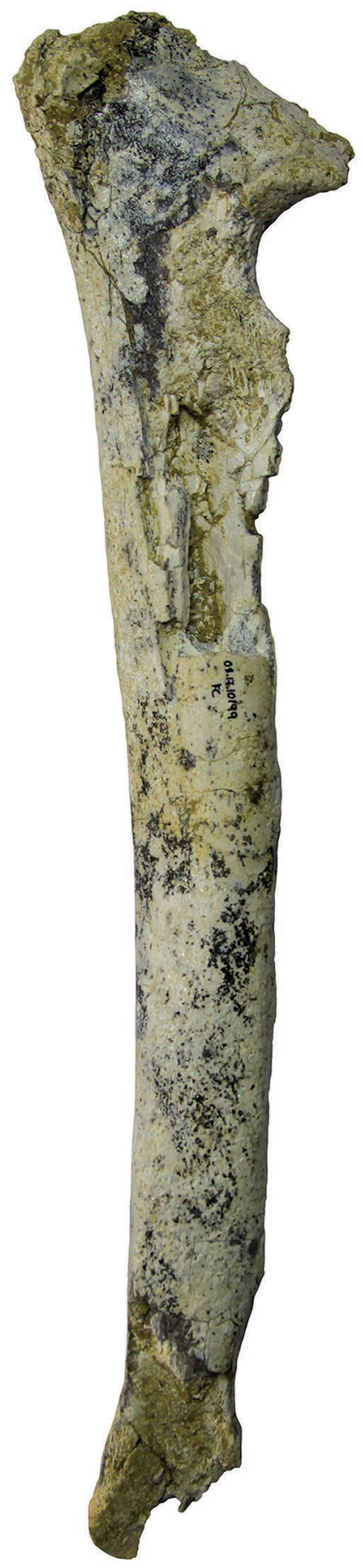

D

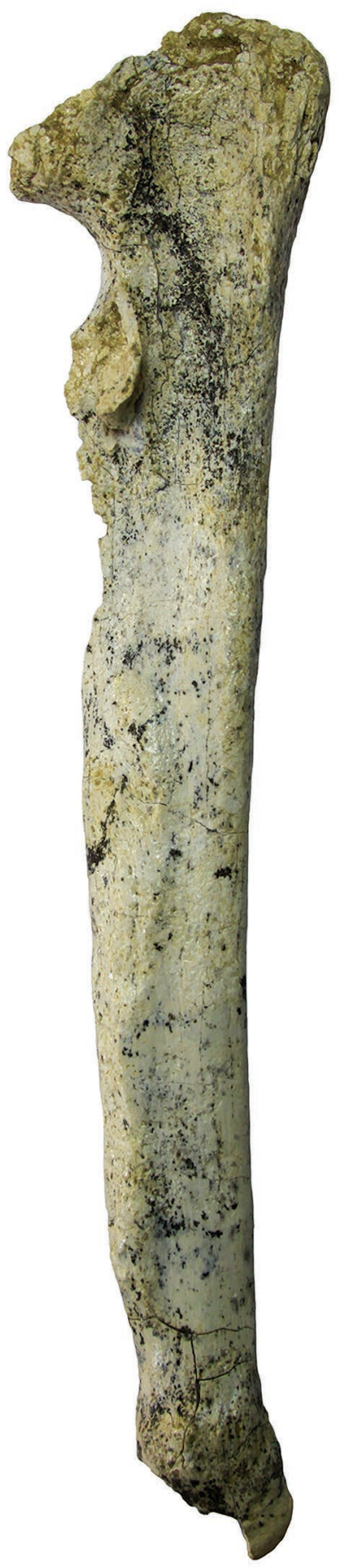

FIG. 3. - Radius and ulna of Megamphicyon giganteus (Schinz, 1825) from Carpetana. Right radius 08.17.10200FC-1: A, cranial view; B,caudal view. Left ulna 08.17.10199FC: C, lateral view; D, medial view. Scale bar: $5 \mathrm{~cm}$

of the two specimens, the proximal epiphysis only preserves a small portion of the craniomedial border, and the cranial half of the proximal articular surface (= fovea capitis). The craniomedial border shows a small eminence, proximally projected, also observed in other amphicyonids, such as $A$. major or Ma. anceps (Argot 2010; Siliceo 2015). The proximal surface is mainly concave, but there is a small, more or less flat medial portion, which is medially inclined. Along the diaphysis of the radius there are several muscle attachment surfaces; the most marked is the bulky and proximodistally extended radial tuberosity on the proximal portion of the caudal face of the radius, which is the attachment area for the $m$. biceps brachii. Close to this tuberosity, and laterocranially located, there is a very rough surface for the attachment of the lateral collateral 
A

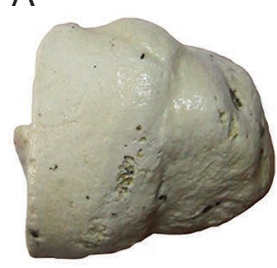

$\mathrm{B}$

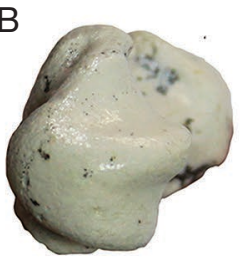

C

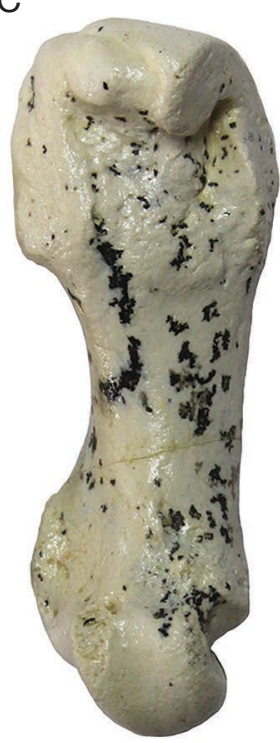

$\mathrm{D}$

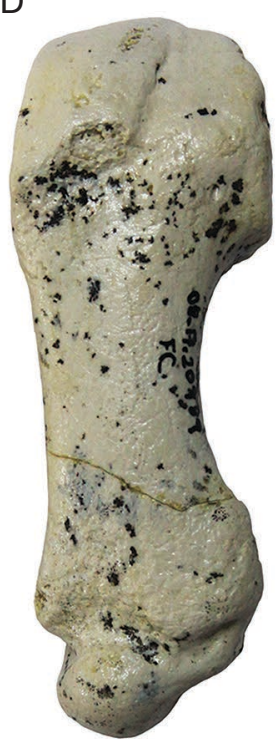

E

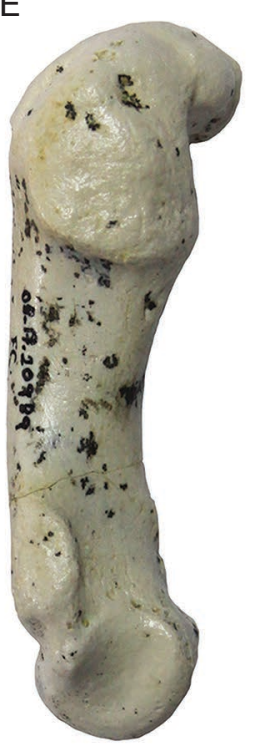

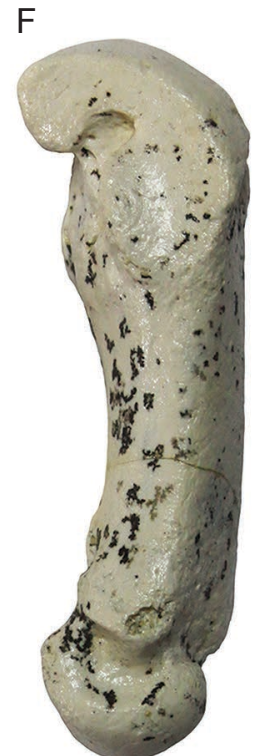

FIG. 4. - Left Mc V 08.17.20989FC of Megamphicyon giganteus (Schinz, 1825) from Carpetana: A, proximal view; B, distal view; C, palmar view; D, dorsal view; E, lateral view; F, medial view. Scale bar: $2 \mathrm{~cm}$.

ligament running from the lateral epicondyle of the humerus. Distally to the radial tuberosity, along the caudal face of the diaphysis, the marked rugosities of the interosseous border can be observed, which is the attachment area for the strong interosseous ligaments described above. Both the radial tuberosity and the rugosities of the interosseous border are very well developed in amphicyonines, more than in most extant carnivorans (felids, canids, ursids or mustelids). Distally to the interosseous border, and caudomedially located there is a well-defined triangular area, delimited proximally by the most distal of the rugosities of the interosseous border, and distally by the distal epiphysis. This is the attachment area for the $m$. pronator quadratus.

In the distal epiphysis, the articular surface for the scapholunar is elliptical and concave, and the styloid process is moderately distally projected; proximally to the styloid process there is a broad and rough tuberosity for the attachment of the $\mathrm{m}$. brachioradialis. The cranial and lateral surface of the distal epiphysis is damaged, and thus, the articular surface for the ulna and the muscular grooves of this area are not visible.

\section{Ulna}

The ulna of $M$. giganteus from Carpetana (08.17.10199FC) is long, stoutly built, and gently curved caudally (Fig. 3C, D). The proximal and distal epiphyses are partially broken. The olecranon is partially damaged, and thus the morphology of the tuber olecrani and the proximal tubercles cannot be described. However, the cranial profile of the olecranon is partially preserved and it seems slightly caudally inclined; also, although it is not possible to know its actual length, the preserved portion of the olecranon is similarly developed as in other amphicyonids such as $A$. major, so the length would probably be comparable. Among amphicyonine amphicyonids, there are differences in the length and morphology of the olecranon: A. major,
M. giganteus, Amphicyon galushai Hunt, 2003 and Ysengrinia americana (Wortman, 1901) show a more developed and caudally inclined olecranon than that of Pseudocyon sansaniensis Lartet, 1851, Amphicyon ingens Matthew, 1924 or Magericyon anceps, with the latter showing a shorter and not caudally inclined olecranon with its short cranial border almost straight in lateral view (Ginsburg 1961a; Ginsburg \& Antunes 1968; Hunt 2002, 2003; Argot 2010; Siliceo 2015).

The lateral side of the proximal epiphysis of the ulna is markedly concave and is mostly occupied by the attachment of the $m$. anconeus. The crested caudal border of this side is the attachment area for the lateral branch of the $m$. triceps brachii. The incisura trochlearis and incisura radialis are partially damaged and only the caudolateral part of the incisura radialis is preserved and laterally projected. The incisura trochlearis only preserves its proximal portion, which constitutes the anconeus process.

Along the diaphysis, the most remarkable feature is the large, and markedly rugose interosseous border, a laterocranially developed surface, homologous with a similar surface on the caudal side of the radius diaphysis. This border occupies most of the lateral face of the diaphysis of the ulna, and is the attachment area for the membrana interossea and lig. interosseous, strong ligaments connecting the radius and ulna. Along this interosseous border, the attachment areas for several muscles, such as the m. abductor digiti I longus and the $m$. extensor digiti I and II, are located.

\section{$M c V$}

The left Mc V of the amphicyonid from Carpetana (08.17.20989FC) (Fig. 4A-F) is even larger than the Mc V from Pontlevoy assigned to A. giganteus by Ginsburg \& Antunes (1968). The total length of the piece from Carpetana is $84.06 \mathrm{~mm}$, whereas that from Pontlevoy is only $79.50 \mathrm{~mm}$. The proximal base of 08.17.20989FC is markedly wide, showing a rectangular, dorsopalmarly elongated 


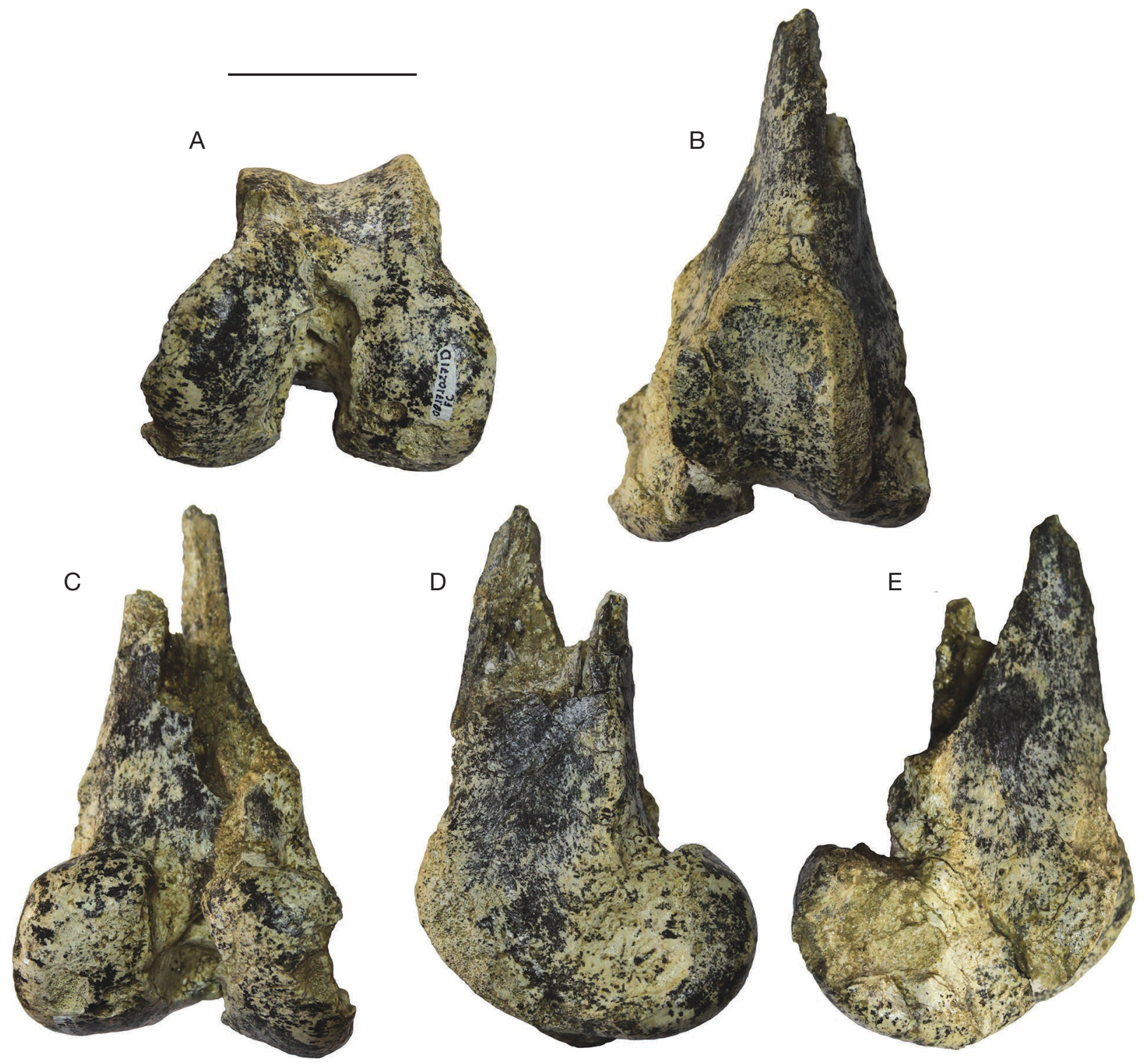

FIG. 5. - Distal fragment of right femur 08.17.10271DFC of Megamphicyon giganteus (Schinz, 1825) from Carpetana: A, distal view; B, cranial view; C, caudal view; D, medial view; E, latera view. Scale bar: $5 \mathrm{~cm}$.

and convex proximal articular surface with the unciform. Palmar to this surface there is a small, rounded tuberosity, and on the lateral side of the proximal base, there is a large, bulky protuberance for the attachment of the m. extensor carpi ulnaris. The articular surface for the Mc IV is dorsopalmarly developed on the medial face of the proximal base. The body of the Mc V is slightly dorsopalmarly flattened, with a fairly smooth surface, without irregularities. Distally, the Mc V is mediolaterally wide, with an asymmetric distal articular head. Close to the distal head on the palmar and lateral faces there are two marked tuberosities: the palmar one is smaller and is the attachment area for the $m$. adductor digiti $\mathrm{V}$, whereas the lateral one is laterally projected and is the probable attachment area for the $m$. abductor digiti $\mathrm{V}$. The general morphology of this metacarpal is similar to that of other amphicyonines such as $A$. major (Argot 2010) and Y. americana (Hunt 2002).

\section{Femur}

Only the distal epiphysis of the right femur 08.17.10271DFC is preserved (Fig. 5A-E). Although it is partially damaged, the distal articular surface (femoral trochlea and lateral and medial condyles) is present, and the rough and slightly inflated surface of the lateral and medial epicondyles is observable. The femoral condyles are similar in width, with the medial one showing a more convex surface than the lateral one. It is not possible to know if the condyles had a similar degree of caudal or distal projection due to a fracture affecting the lateral condyle. The two condyles are separated by a deep, broad and symmetric intercondylar fossa. On the caudal side of the epiphysis, just above the condyles, there are two fossae for the sesamoids of the lateral and medial tendons of the $m$. gastrocnemius (Barone 2010a, b). The femoral trochlea shows a quadrangular shape, its proximodistal length being slightly 
A

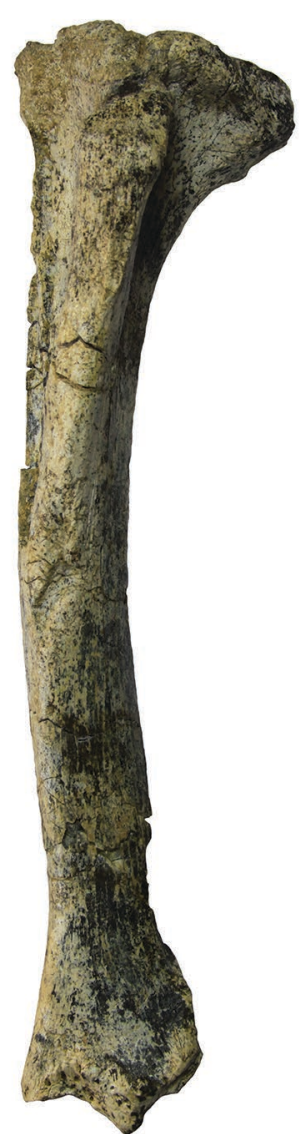

B

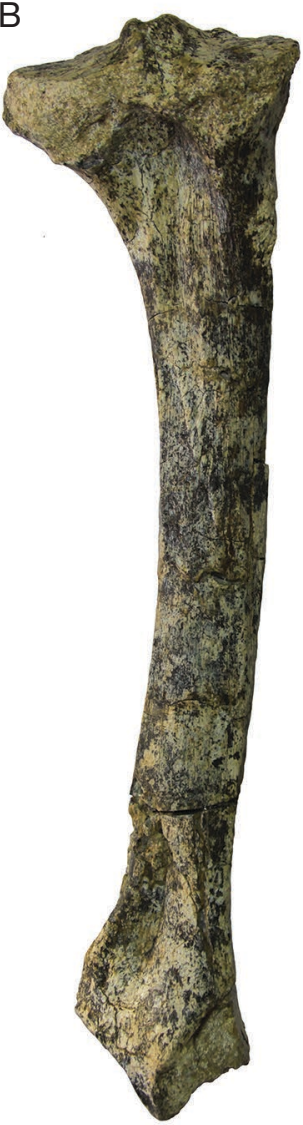

C

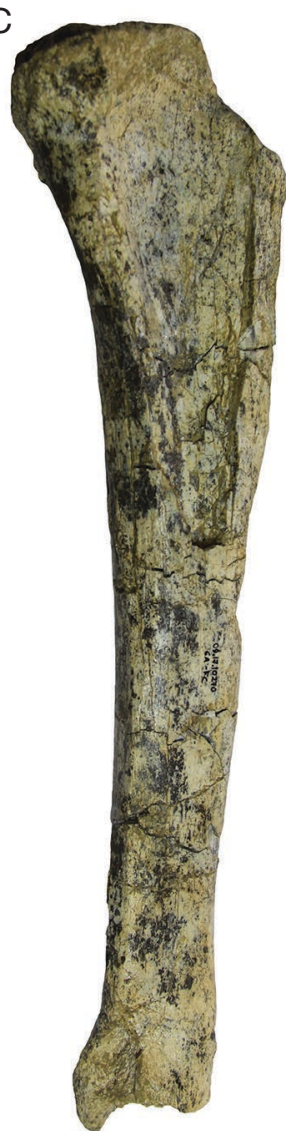

D

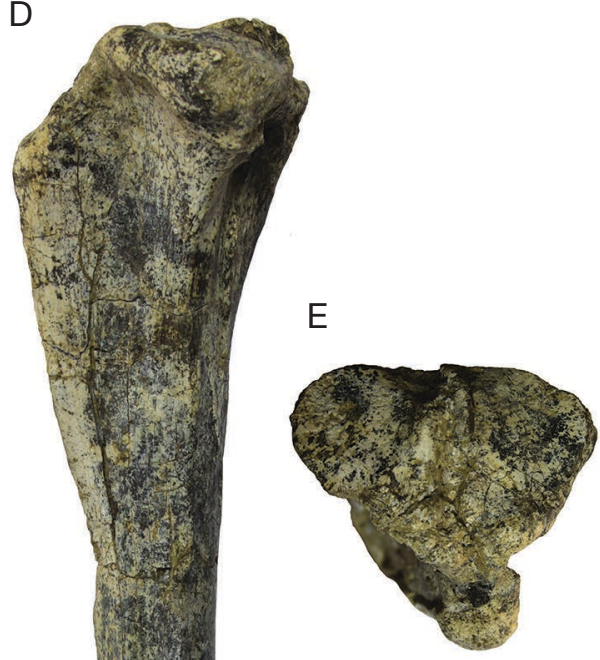

$\mathrm{F}$
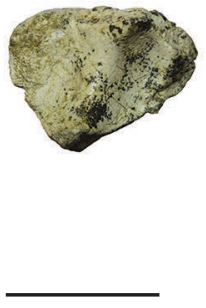

FIG. 6. - Left tibia 08.17.10270-6A-FC of Megamphicyon giganteus (Schinz, 1825) from Carpetana: A, cranial view; B, caudal view; C, medial view; D, lateral view; E, proximal view; F, distal view. Scale bar: $5 \mathrm{~cm}$.

greater than its lateromedial width. The trochlear surface is concave but not very deep, with prominent lateral and medial borders. In distal view the distal epiphysis is approximately as wide as high $(\mathrm{w}=92.53 \mathrm{~mm} ; \mathrm{h}=91.13 \mathrm{~mm})$, with a greater craniocaudal development of both trochleae and femoral condyles than those of ursids. The femoral condyles also are more proximodistally developed than those of ursids. In overall view, the distal epiphysis of the amphicyonid from Carpetana shows an intermediate morphology between those of felids and ursids, similarly to typical amphicyonines such as A. major (Argot 2010).

\section{Tibia}

An almost complete left tibia (08.17.10270-6A-FC) (Fig. 6A-F) from Carpetana is preserved, with only the medial portion of the distal epiphysis and the malleolus missing. This tibia is similar to that of other amphicyonines, such as $A$. major, in not being particularly robust, in contrast to that of $Y$. americana (Hunt 2002), and showing a marked lateral curvature. The proximal epiphysis is triangular in proximal view, and it is mainly occupied by the lateral and medial tibial condyles (for the articulation with the femoral condyles), which are slightly caudally inclined; there is also a marked cranially projected tibial tuberosity. The cranial projection of the tibial tuberosity of the Carpetana tibia is, like that of other amphicyonines, more similar to that of felids than to that of ursids. It is rough, with a marked scar for the patellar ligament (the distal portion of the m. quadriceps femoris joining the patella and tibia) on its distal border. Distally from the tibial tuberosity, the tibial crest for the attachment of $m$. sartorius, $m$. gracilis and $m$. semitendinosus is developed until the middle of the cranial border of the diaphysis. On the caudolateral margin of the lateral condyle, there is an elliptical facet for the articulation with the fibula, and cranially to it there is a rough surface for the attachment of the $m$. fibularis longus. The lateral face of the proximal epiphysis is occupied by the tibial fossa, which shows a rough and markedly concave surface. On the cranial portion of this fossa, close to the tibial tuberosity, there is the attachment area for the $m$. tibialis cranialis.

The medial border of the distal epiphysis of the tibia from Carpetana is damaged, and in consequence, the medial malleolus is lacking. The distal surface has its craniocaudal axis slightly medially oriented, and shows two concave grooves separated by a convex surface for the articulation with the talus. On the cranial and caudal borders of the epiphysis, there are two distal projections, coinciding with the central separation of the distal grooves. The concavity of this distal articulation surface is, like in other amphicyonines, more similar to that of large felids than to that of ursids; that of the latter group has a shallower articular surface for the talus. On the lat- 
A

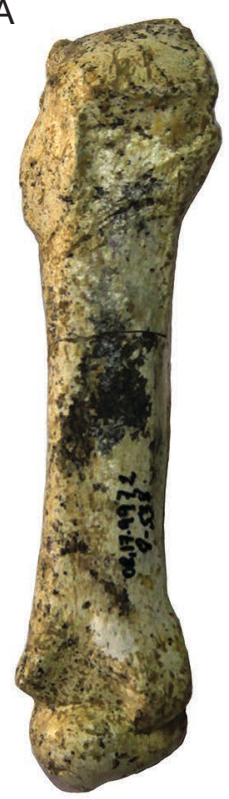

B

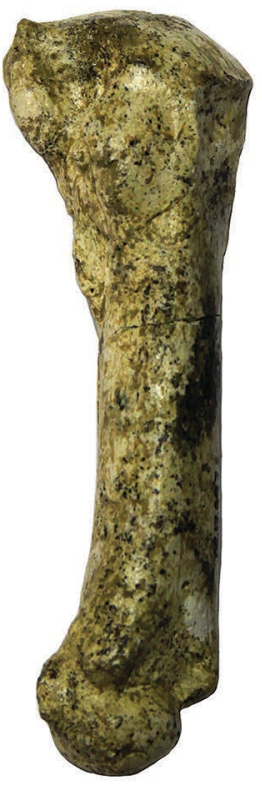

C

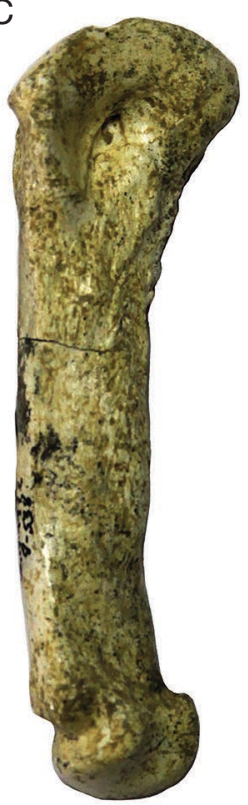

D

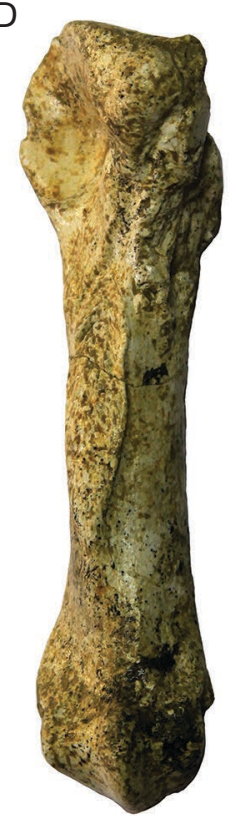

E

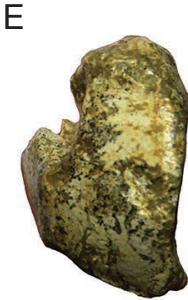

F

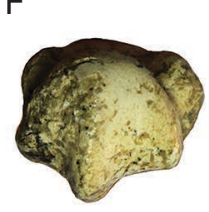

FIG. 7. - Left Mt IV 08.17.99728-538 of Megamphicyon giganteus (Schinz, 1825) from Carpetana: A, dorsal view; B, medial view; C, lateral view; D, plantar view; E, proximal view; $\mathbf{F}$, distal view. Scale bar: $2 \mathrm{~cm}$.

eral margin of the distal articulation surface there is a small semicircular facet for the articulation with the distal fibula. The cranial and lateral borders of the epiphysis are markedly rough and show several small tuberosities and foramina, which are probably scars of the tarsocrural articular capsule. The caudal surface of the diaphysis shows the typical pattern of muscle scars seen in other amphicyonines, composed of two obliquely developed lines that delimit the area of several muscles. These lines define a marked and narrow groove for the $m$. flexor digitorum medialis and $m$. tibialis caudalis on the proximal half of the caudal surface; the medial line (the popliteal line) demarcates a triangular area, proximally and medially, for the attachment area for the $m$. popliteus; and finally, the lateral area constitutes the attachment surface for the $m$. flexor digitorum lateralis (Barone 1967, 2010a, b; Evans 1993). Distally, both lines end on the medial border, in the middle of the diaphysis.

\section{Mt IV}

The Mt IV of $M$. giganteus from Carpetana (08.17.99728538) is fairly complete (Fig. 7A-F). The proximal base is dorsoplantarly lengthened, showing a rectangular and convex facet with a slightly proximally projected medioplantar vertex for the articulation with the cuboid. On the medial face there are two facets, the proximodorsal one being markedly larger than the proximoplantar one. The proximal margin of both facets articulates with the ectocuneiform, whereas the rest of the margin, and most of the surface of the facets, articulate with the Mt III. The two facets are separated by a small rugose fossa where one interosseous ligament attaches. The lateral face of the proximal base is mostly occupied by a wide fossa and by the articulation surface with the Mt V on the proximodorsal portion. On the proximoplantar end there is a marked plantar tuberosity, and distal to that, there is a rough surface for the $m$. interosse $i \mathrm{IV}$.

On the lateroplantar margin of the body there is a rough and proximodistally developed fusiform surface, typical of this metatarsal, which is probably the attachment area for the long plantar ligament (Barone 2010b). The distal head of the Mt IV is globular as in other metapodials, being just slightly asymmetric.

\section{BODY MASS ESTIMATION}

We estimated the body mass of Megamphicyon giganteus with the formula of Figueirido et al. (2011) for Amphicyonidae, using two tibial measurements: the mediolateral width of the diaphysis at the midshaft, and the craniocaudal diameter of the distal epiphysis. These measurements do not show the best correlation to body mass (Figueirido et al. 2011) but due to the state of preservation of the fossils from Carpetana, we could only use the tibia. As a result, a body mass estimation of $595.50 \mathrm{~kg}$ was obtained for the specimen of $M$. giganteus (08.17.102706A-FC) from Carpetana. However, this result should be taken with caution because the body mass obtained from the tibia formula may be somewhat overestimated. As an example, the body mass estimation for Amphicyon ingens based on the medio-lateral diameter of the femur at the middle of the diaphysis, a measure that shows the best correlation to body mass, results in an estimated body mass of $547 \mathrm{~kg}$ (Figueirido et al. 2011), whereas the estimation based on tibial measurements results in an estimated body mass of $786 \mathrm{~kg}$; thus, the difference between the two estimates is around $200 \mathrm{~kg}$. On the other hand, the difference between these two estimates (obtained from femoral and tibial measurements) for the 
amphicyonids Ysengrinia americana and Ischyrocyon gidleyi is only around 25-60 kg (Figueirido et al. 2011).

Although the body mass of $M$. giganteus may be overestimated, the difference in the size of the studied bones compared to those of $A$. major (Fig. 8) suggests that the body mass of $M$. giganteus would be above that estimated for $A$. major $(140-183 \mathrm{~kg})$. Thus, an estimated body mass of $595.50 \mathrm{~kg}$ may be not far from its actual size. In any case, even taking into account the probable overestimation of the body mass of this amphicyonid, $M$. giganteus would be one of the largest known amphicyonine species, as it is close to the size range of the gigantic North American amphicyonine Amphicyon ingens, with an estimated body mass of 547-706 kg (Sorkin 2006; Figueirido et al. 2011), and thus surpassing the body mass of other large amphicyonines such as Amphicyon major, with an estimated body mass of 140-183 kg (Argot 2010; Figueirido et al. 2011), Ysengrinia americana, with around $173-231 \mathrm{~kg}$ (Figueirido et al. 2011), Amphicyon galushai, with 191-204 kg (Figueirido et al. 2011), and Magericyon anceps, with a body mass of 172-199 kg (Siliceo et al. 2015).

In summary, the estimated body mass of $M$. giganteus places this species among the largest known amphicyonines (genera Amphicyon, Ischyrocyon, Ysengrinia and Pseudocyon), all weighing more than $150 \mathrm{~kg}$. With this size, $M$. giganteus would have been the top predator of the mammalian communities of the lower and middle Miocene, and only in those habitats where the giant creodont Hyainailouros Stehlin, 1907 was present, would this large amphicyonid have faced an upto-scratch opponent.

\section{FUNCTIONAL IMPLICATIONS OF THE POSTCRANIAL ANATOMY OF MEGAMPHICYON GIGANTEUS}

The fossil material of $M$. giganteus from Carpetana is not especially abundant or well preserved, but it shows some morphological features with relevance for functional analysis. In this section, we focus on those structures in order to infer some aspects of the ecology and functional anatomy of this large predator.

Concerning the forelimb, both the radius and ulna show severely damaged epiphyses, which prevent the observation and study of most of the structures with functional interest; anyway, there are some features that provide biomechanical information: the great development of the radial tuberosity of the radius and the rugosities of the interosseous border in radius and ulna, which are similarly developed in other amphicyonines (Argot 2010; Siliceo 2015). The radial tuberosity is the attachment surface for the $m$. biceps brachii, the main flexor of the elbow (Davis 1964; Gambaryan 1974; Barone 2010b), and thus, the great development of this tuberosity suggests the presence of a strong muscle and in consequence, a great capacity for elbow flexion (Taylor 1974). The interosseous border is the attachment area for the membrana interossea and lig. interosseous, both strong ligaments connecting the radius and ulna, which prevents wrist dislocation during supination

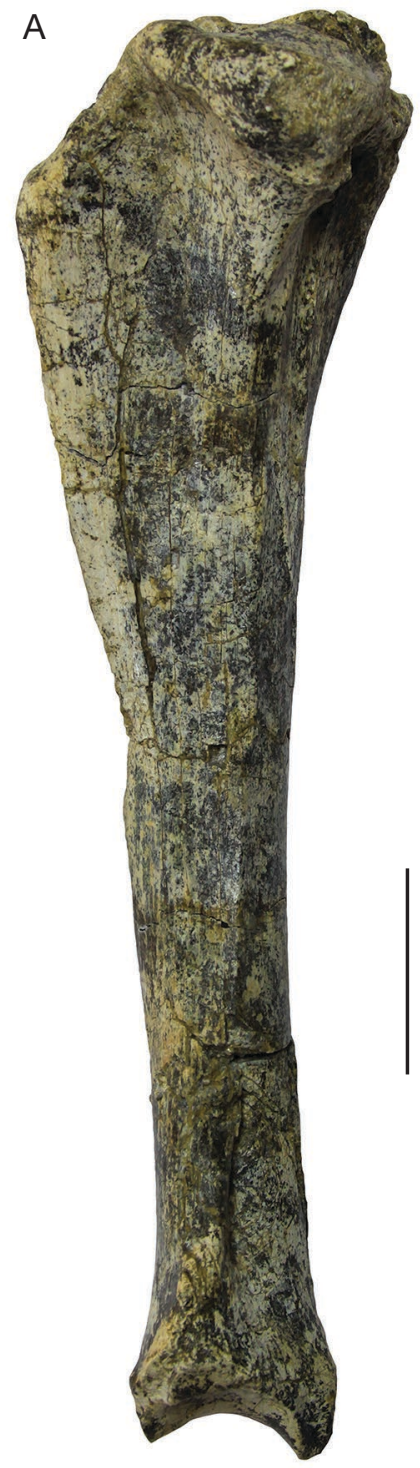

\section{B}

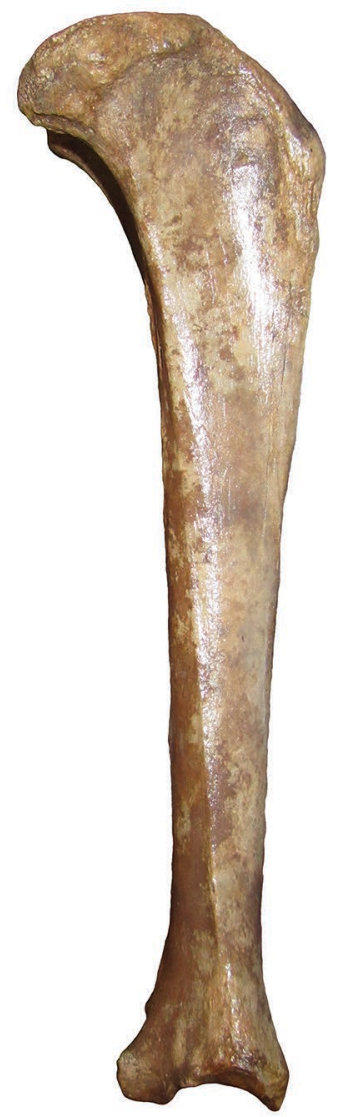

FIG. 8. - Comparison between the left tibia of Megamphicyon giganteus (Schinz, 1825) (A) and the right tibia of Amphicyon major Blainville, 1841 (B) in lateral view, showing their strong size differences. Scale bar: $5 \mathrm{~cm}$.

and pronation movements (Taylor 1974; Evans 1993; Barone 2010b). As suggested for other amphicyonines, M. giganteus could have exhibited high pronation/supination capacity, and the greater development of the membrana interossea could help in the control of these movements of the forearm.

The better preservation of the hindlimb elements of $M$. giganteus, the distal epiphysis of the femur and the complete tibia, allows a deeper analysis of their functional morphology. The distal epiphysis of the femur of $M$. giganteus from Carpetana shows an intermediate morphology between those of felids and ursids, as observed in other amphicyonines such as A. major (Argot 2010). In distal view, the femoral epiphysis of amphicyonids shows similar mediolateral width and craniocaudal length, a pattern that separates them from other large carnivorans. In ursids the mediolateral width is greater than the craniocaudal length, whereas in felids and canids, the craniocaudal length is the greater of these two (Fig. 9A-D). These different morphologies have been linked to different 

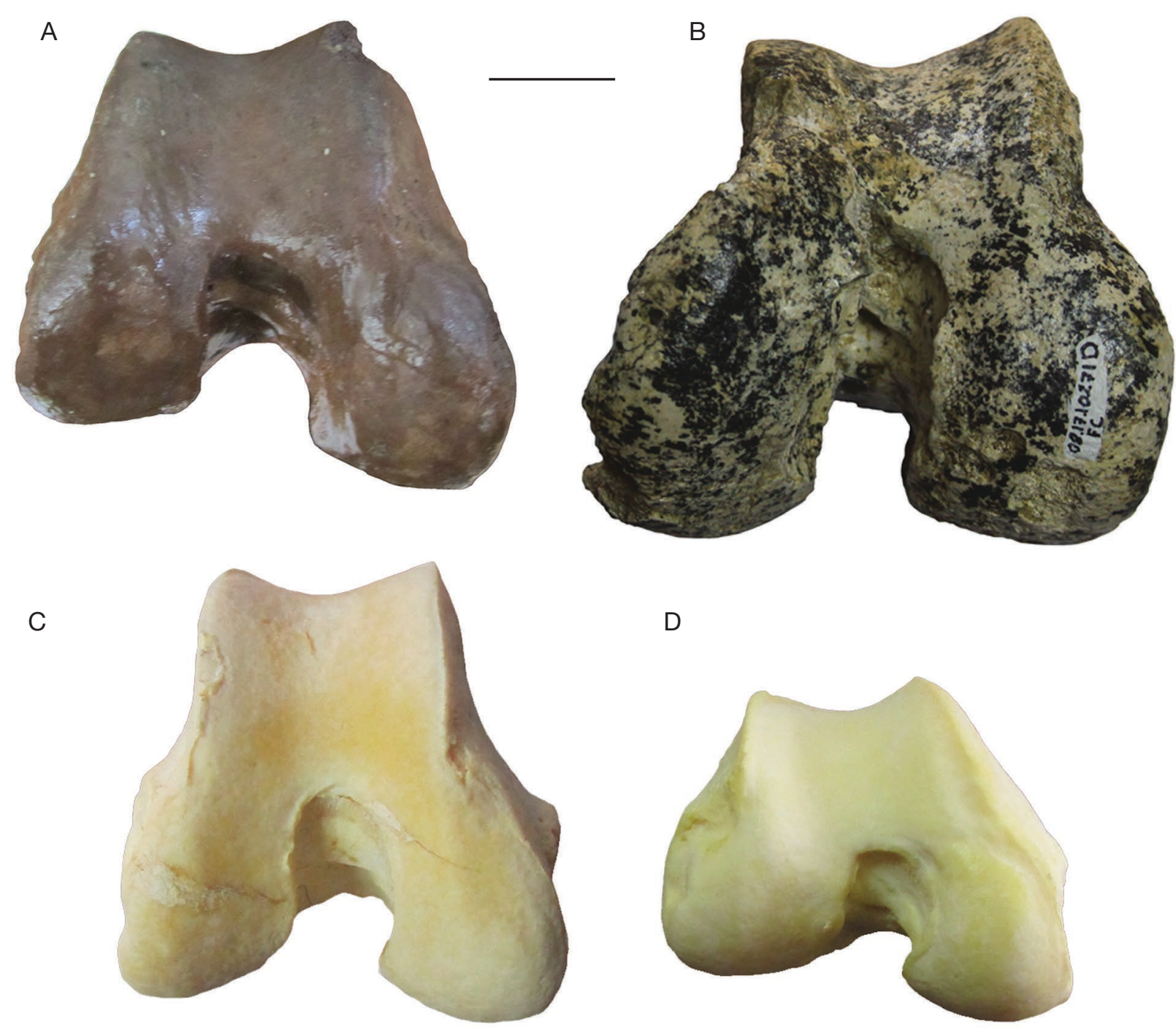

FIG. 9. - Comparison between the distal epiphyses of the right femur of several carnivorans, in distal view: A, Amphicyon major Blainville, 1841 from Sansan; B, Megamphicyon giganteus (Schinz, 1825) from Carpetana; C, Panthera leo (Linnaeus, 1758); D, Ursus americanus Pallas, 1780. Scale bar: 2 cm.

locomotor modes: a mediolaterally wider distal epiphysis of the femur has been associated to an unspecialized terrestrial locomotion (as seen in ursids or procyonids) or to arboreal adaptations (such as that of several species of ailurids, mustelids and viverrids), whereas a relatively mediolaterally narrow distal epiphysis, such as those seen in canids, felids and hyaenids, has been found to be indicative of cursorial specializations (Taylor 1976; Argot 2002, 2003). These differences are mainly due to the development of the femoral trochlea and the condyles, and thus the trochlea is more proximodistally developed in carnivorans with a relatively high and concave distal epiphysis, which has been explained as being related to a relatively wide range of patella movement, and with a great range of extension of the knee (Howell 1944; Taylor 1976). In addition, a more concave trochlea suggests that movements of the knee are more restricted to the parasagittal plane (Howell 1944; Taylor 1976). The morphology seen in M. giganteus, although similar overall to that of terrestrial carnivorans without marked cursorial specializations (for example, ursids), also shows some differences such as the more proximodistally developed and more concave trochlea (with more prominent lateral and medial borders), which would suggest a strong necessity for patella stabilization during knee flexion, but also a higher range of extension in this articulation, both of them indicative of good running abilities.

The tibial tuberosity of $M$. giganteus shows some differences with those of extant carnivorans that could point towards a different efficiency of the $m$. quadriceps femoris during the extension of the knee. The tibial tuberosity of $M$. giganteus is more similar to that of felids in showing a distinct cranial projection (Fig. 10A-B), and it is markedly different from that of ursids, in which this tuberosity is barely projected at all (Fig. 10C). In canids the tuberosity is even more cranially and proximally projected than in felids and amphicyonids. A more cranioproximally projected tibial tuberosity implies a more cranially located tuberosity in relation to the tibial condyles, which increases the distance between the attachment point of the $m$. quadriceps femoris and the centre of rotation 


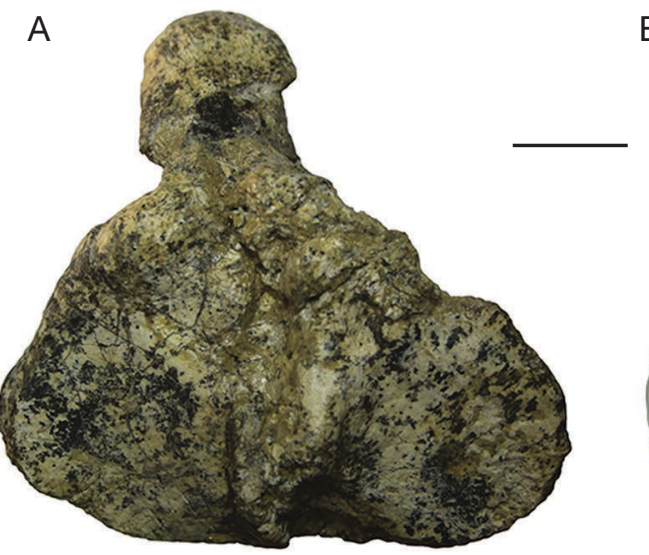

B

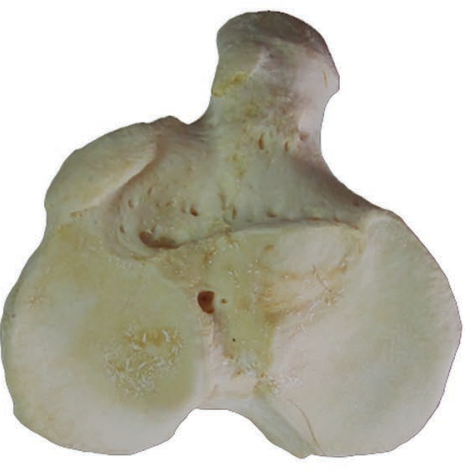

C

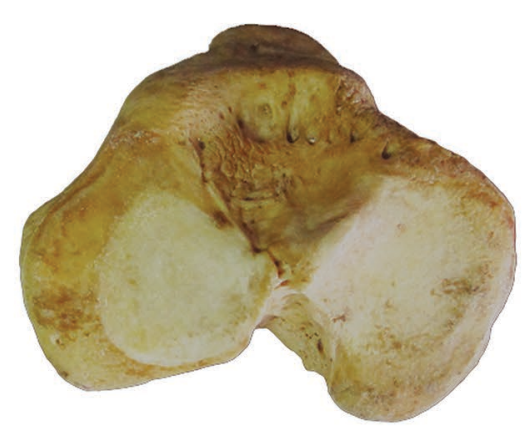

FIG. 10. - Comparison between the proximal epiphyses of the left tibia of several carnivorans, in proximal view: A, Megamphicyon giganteus (Schinz, 1825) from Carpetana; B, Panthera leo (Linnaeus, 1758); C, Ursus americanus Pallas, 1780 . Scale bar: 2 cm.

of the knee articulation. This increases the lever-arm of this powerful extensor of the knee (Feeney 1999), as well as the strength of the movement and the range of extension. The maximum range of knee extension is reached at the end of the support phase of the hindlimb, during the propulsion with the hindlimbs, when coxofemoral, knee and talocrural articulations are extended (Gambaryan 1974). An increase in the extension range of these articulations contributes to the whole extension of the hindlimb during propulsion, improving the efficiency of this articulation. These features of the knee of $M$. giganteus are remarkable because, despite the gigantic size of this amphicyonid, it had a relatively efficient knee, a part of the locomotor apparatus implicated in the generation of propulsive force for terrestrial locomotion (Gambaryan 1974; Taylor 1976; Alexander 1988).

Another interesting feature of the tibia of $M$. giganteus is the pattern of muscular scars on its caudal surface, which is very similar to that of other amphicyonines such as $A$. major. The width of the groove for the tendons of the $m$. flexor digitorum medialis and $m$. tibialis caudalis has been related to a digitigrade or plantigrade posture (Ginsburg 1961b; Wang 1993; Siliceo 2015). Following Ginsburg (1961b), plantigrade carnivorans, such as ursids, show a larger attachment area for the $m$. flexor digitorum medialis and $m$. tibialis caudalis than digitigrade carnivorans (Davis 1964). On the other hand, felids have a smaller, narrower and less marked attachment area than ursids, whereas canids show the most reduced one. However, there is some variation within the pattern observed in felids, with $P$. leo showing a relatively broad attachment area for these muscles, whereas in the cheetah (Acinonyx jubatus (Schreber, 1775)) it is markedly narrower and more similar to that of canids. Thus, although the different patterns have been related to plantigrade or digitigrade posture, a reduction in the attachment area for the $m$. flexor digitorum medialis and $m$. tibialis caudalis seems to be more related to a reduced functional importance of the $m$. tibialis caudalis in locomotion (Hunt 2009). These muscles have their mass restricted to the proximal portion of the tibia, showing long and narrow tendons running along the caudal face of the tibial diaphysis (Barone 1967, 2010b; Evans 1993). In A. jubatus and the canid Canis lupus these tendons are extremely long and narrow, as is typical of cursorial carnivorans, which reduce the weight of the distal portions of their extremities by placing the muscle masses in the most proximal segments, and also reducing the muscular work and the energy employed (Alexander 1988, 2002). The $m$. tibialis caudalis is an extensor of the tarsus and an outward rotator of the foot (Evans 1993; Barone 2010b), and thus its reduction, and the presence of flexor muscles with long tendons, are adaptations to efficient flexion-extension of the tarsus and digits, something essential for a cursorial carnivoran. The morphology of this caudal surface of the tibia in $M$. giganteus, as in other large amphicyonines such as $A$. major, shows an intermediate pattern between those of ursids and large felids; this is striking, because despite the large size of $M$. giganteus, it showed more advanced cursorial features than ursids, at least in the discussed character of the tibia.

In summary, both the overall anatomy and the estimated body mass of $M$. giganteus suggest that it was a large and powerful amphicyonid, with an appendicular skeleton showing better running abilities than those of ursids. This would have probably placed $M$. giganteus as one of the top predators of the middle Miocene mammalian communities (Fig. 11).

\section{CONCLUSIONS}

Our functional analysis of some aspects of the anatomy of Megamphicyon giganteus from Carpetana (Madrid) supports our previous studies noting the singularity of the amphicyonid anatomy, which for many features is intermediate between that of ursids and felids. This is even more interesting when we consider the gigantic size of $M$. giganteus, one of the largest amphicyonids, with an estimated body mass of around $600 \mathrm{~kg}$, and the presence in its habitat of other large predators, such as barbourofelids, creodonts and even sympatric species of Amphicyonidae. The morphology of its hindlimb indicates greater cursorial capacities than 


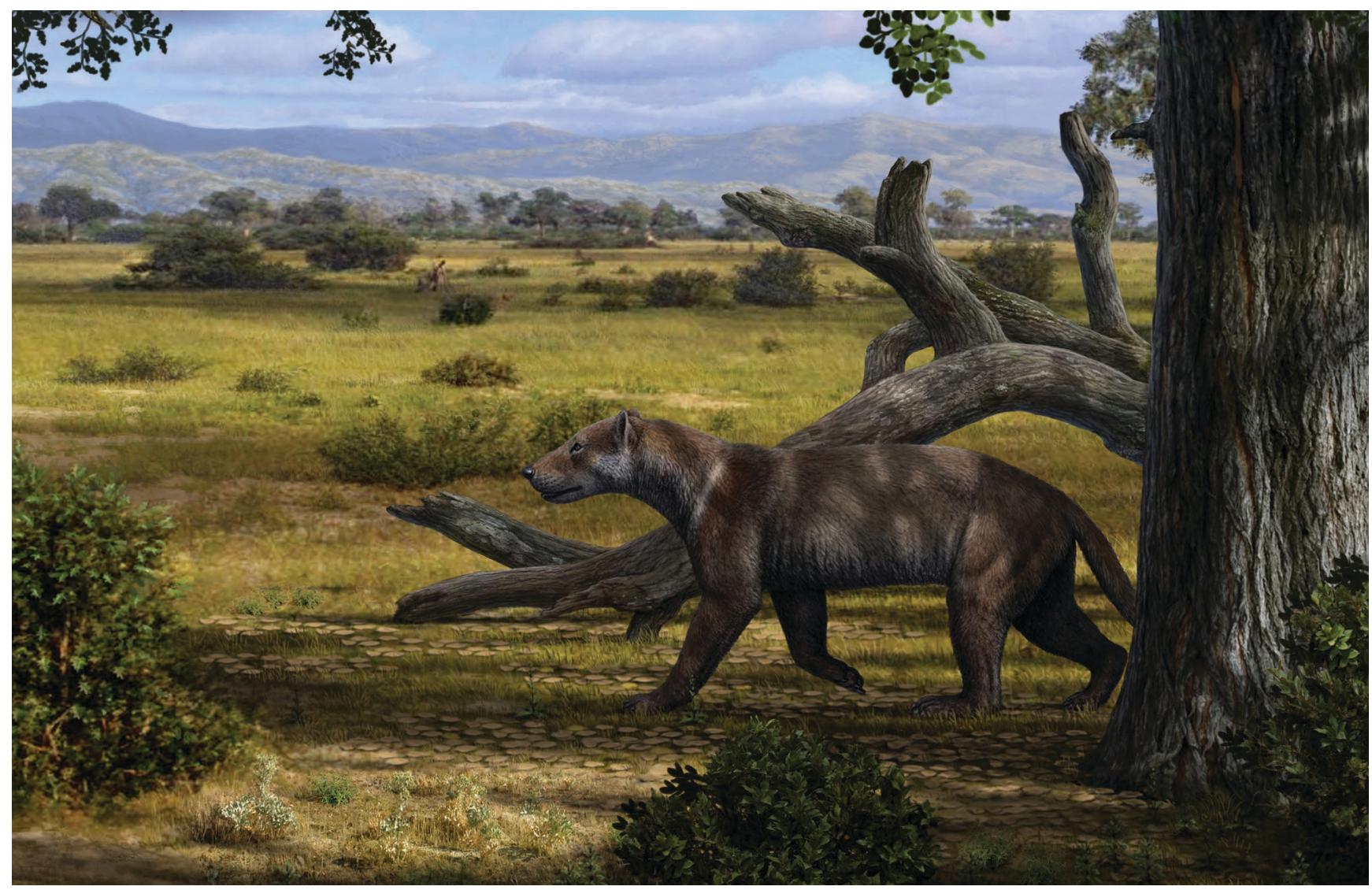

FIG. 11. - Reconstruction of the life appearance of Megamphicyon giganteus (Schinz, 1825) in the Miocene habitat of the Carpetana fossil site (artwork by M. Antón).

other large predators such as bears: for example, the distal epiphysis of femur is mediolaterally narrower, the trochlea is more proximodistally developed and more concave, and the tibial tuberosity is much more cranially projected; on the other hand, the forelimb was strong, with the radius and ulna showed a high capacity of pronation/supination movements. These features are also seen in other large amphicyonids, such as $A$. major, but further finds of fossils of $M$. giganteus, especially of its appendicular and axial skeleton, are needed to understand the ecological role and anatomical adaptations of this incredible predator, and its functional differences with other amphicyonids.

\section{Acknowledgements}

This study is part of the research project CGL2015-68333-P (MINECO/FEDER, UE). GS is member of the research group "Bioacústica Evolutiva y Paleoantropología". JM is member of the research groups UCM-BSCH-910607, and CSIC-641538. MJS is member of the research groups CSIC-641538, and FOCONTUR (Fundación Conjunto Paleontológico de Teruel-Dinópolis). We thank Dr Juan Francisco Pastor (Museo Anatómico, Universidad de Valladolid, Spain), Dr Josefina Barreiro (Museo Nacional de Ciencias Naturales-CSIC), and Dr Christine Argot (Muséum national d'Histoire naturelle, Paris, France) for kindly loaning the specimens used for comparison. We thank the government of the Comunidad de Madrid (Spain) for the permission for studying the fossils from Carpetana site. We would like to dedicate this work to the memory of our friend and colleague Stéphane Peigné; when writing this paper, we missed him many times, as one of the most renowned specialists in Amphicyonidae, but also as that friend with whom we shared wonderful personal and professional moments.

\section{REFERENCES}

AleXander R. M. 1988. - Elastic Mechanisms in Animal Movement. Cambridge University Press, Cambridge, 150 p.

AlEXANDer R. M. 2002. - Tendon elasticity and muscle function. Comparative biochemistry and physiology part a: Molecular \& integrative physiology 133 (4): 1001-1011. https://doi. org/10.1016/S1095-6433(02)00143-5

ARGOT C. 2002. - Functional-adaptive analysis of the hindlimb anatomy of extant marsupials and the paleobiology of the Paleocene marsupials Mayulestes ferox and Pucadelphys andinus. Journal of Morphology 253: 76-108. https://doi.org/10.1002/ jmor. 1114

ARGOT C. 2003. - Functional adaptations of the postcranial skeleton of two Miocene borhyaenoids (Mammalia, Metatheria), Borhyaena and Prothylacinus, from South America. Palaeontology 46: 1213-1267. https://doi.org/10.1046/j.00310239.2003.00339.x 
ARGOT C. 2010. - Morphofunctional analysis of the postcranium of Amphicyon major (Mammalia, Carnivora, Amphicyonidae) from the Miocene of Sansan (Gers, France) compared to three extant carnivores: Ursus arctos, Panthera leo, and Canis lupus. Geodiversitas 32: 65-106. https://doi.org/10.5252/g2010n1a2

Barone R. 1967. - La myologie du lion (Panthera leo). Mammalia 31: 459-516. https://doi.org/10.1515/mamm.1967.31.3.459

Barone R. 2010a. - Anatomie comparée des Mammiferes domestiques, tome premier, Ostéologie (5e édition). Éditions Vigot Frères, Paris, $761 \mathrm{p}$.

BARONE R. 2010b. - Anatomie comparée des Mammiferes domestiques, tome second, Arthrologie et Myologie (4e édition). Éditions Vigot Frères, Paris, $1021 \mathrm{p}$.

BEAUMONT G. DE. 1984. - Des dents d'Amphicyon (Mammifere, Carnivore, Ursidé) du Turolien basal de Kohfidisch, Burgenland, Autriche. Archives des Sciences, Genève 37: 75-83.

CUvier G. 1824. - Recherches sur les ossements fossiles ou l'on rétablit les caractères de plusieurs animaux dont les révolutions du Globe ont détruit les espèces. Paris.

DAVIS D. D. 1964. - The giant panda: a morphological study of evolutionary mechanisms. Fieldiana: Zoology Memoirs 3: 1-339. https://doi.org/10.5962/bhl.title.5133

Evans H. E. 1993. - Miller's Anatomy of the dog (3rd edition). Saunders, Philadelphia, 1113 p.

FEENEY S. 1999. - Comparative osteology, myology, and locomotor specializations of the fore and hind limbs of the North American foxes Vulpes vulpes and Urocyon cinereoargenteus. PhD Thesis, University of Massachusetts, Amherst, United States, 534 p.

Figueirido B., Pérez-Claros J. A., Hunt R. M. Jr. \& PalmQvist P. 2011. - Body mass estimation in amphicyonid carnivoran mammals: a multiple regression approach from the skull and skeleton. Acta Palaeontologica Polonica 56: 225-246. https://doi. org/10.4202/app.2010.0005

Fraile S., Pérez B., De Miguel I. \& Morales J. 1997. — Revisión de los Carnívoros presentes en los yacimientos del Neógeno espanol, in CAlvo J. P. \& Morales J. (eds), Avances en el conocimiento del Terciario ibérico, III congreso del Grupo Español del Terciario. Cuenca: Museo Nacional de Ciencias Naturales-CSIC, Universidad Complutense de Madrid: 77-80.

GAGNAISON C. 2013. - Les assemblages de vertébrés dans deux sites paléontologiques du bassin miocène de Savigné-sur-Lathan/Noyantsous-le-Lude: La Guimardière et Pelmer (Maine-et-Loire, France). Geodiversitas 35: 67-103. https://doi.org/10.5252/g2013n1a5

GAGNAISON C. 2017. — Le site paléontologique du Grand Morier (Pont-Boutard, Indre-et-Loire, France): contexte géologique et détail biostratigraphique des formations cénozoïques à partir des assemblages de vertébrés fossiles. Geodiversitas 39: 251-271. https://doi.org/10.5252/g2017n2a5

Gambaryan P. P. 1974. - How mammals run. Anatomical adaptations. John Wiley \& Sons, New York, 367 p.

GINSBURG L. 1961a. — La faune des carnivores miocènes de Sansan (Gers). Mémoires du Muséum national d'Histoire naturelle, Série C 9: 1-190.

GINSBURG L. 1961b. - Plantigradie et digitigradie chez les carnivores fissipedes. Mammalia 25 : 229-238. https://doi.org/10.1515/ mamm.1961.25.1.1

Ginsburg L. 1999. - Order Carnivora, in Rössner G. E. \& HeIssig K. (eds), The Miocene Land Mammals of Europe. Verlag Dr Friedrich Pfeil, München: 109-148.

GiNSBURG L. 2001. - Les faunes de mammifères terrestres du Miocène moyen des Faluns du basin de Savigné-sur-Lathan (France). Geodiversitas 23: 381-394.

GINSBURG L. 2002. — Les carnivores fossils des sables de l'Orléanais. Annales de Paléontologie 88: 115-146. https://doi.org/10.1016/ S0753-3969(02)01042-X

Ginsburg L. \& Antunes M. T. 1968. - Amphicyon giganteus, carnassier géant du Miocene. Annales de Paléontologie, Vertébrés 54: $1-32$.
Hayward M. W., Hofmeyr M., O’Brien J. \& Kerley G. I. K. 2006. - Prey preferences of the cheetah (Acinonyx jubatus) (Felidae: Carnivora): morphological limitations or the need to capture rapidly consumable prey before kleptoparasites arrive? Journal of Zoology 270: 615-627. https://doi.org/10.1111/j.14697998.2006.00184.x

Howell A. B. 1944. - Speed in Animals: Their Specialization for Running and Leaping. University of Chicago Press, Chicago, $270 \mathrm{p}$.

Hunt R. M. JR. 1998. - Amphicyonidae, in Janis C. M., SсотT K. M. \& JACOBS L. L. (eds), Evolution of Tertiary Mammals of North America. Volume I: Terrestrial Carnivores, Ungulates, and Ungulatelike Mammals. Cambridge University Press, Cambridge: 196-227.

HunT R. M. JR. 2001. - Small Oligocene amphicyonids from North America (Paradaphoenus, Mammalia, Carnivora). American Museum Novitates 3331: 1-20. http://hdl.handle.net/2246/2884

HuNT R. M. JR. 2002. - Intercontinental migration of Neogene amphicyonids (Mammalia, Carnivora): appearance of the Eurasian beardog Ysengrinia in North America. American Museum Novitates 3384: 1-53. http://hdl.handle.net/2246/2873

HunT R. M. JR. 2003. - Intercontinental migration of large mammalian carnivores: earliest occurrence of the Old World beardog Amphicyon (Carnivora, Amphicyonidae) in North America. Bulletin of the American Museum of Natural History 279: 77-115. http://doi.org/cd347d

HunT R. M. JR. 2009. - Long-legged pursuit carnivorans (Amphicyonidae, Daphoeninae) from the early Miocene of North America. Bulletin of the American Museum of Natural History 318: 1-95. https://doi.org/10.1206/593.1

HUNT R. M. JR. 2011. — Evolution of large carnivores during the mid-cenozoic of North America: the Temnocyonine radiation (Mammalia, Amphicyonidae). Bulletin of the American Museum of Natural History 358: 1-153. https://doi.org/10.1206/358.1

ICVGAN, International Committee On Veterinary Gross Anatomical Nomenclature. 2017. - Nomina Anatomica Veterinaria (6 $6^{\text {th }}$ edition). World Association of Veterinary Anatomists (W.A.V.A), Hannover (Germany), Columbia MO (USA), Ghent (Belgium), Sapporo (Japan).

Kuss S. 1965. - Revision der europäischen Amphicyoninae (Canidae, Carnivora, Mammalia) ausschliesslich der voroberstampischen Formen. Sitzungsberichte der Heidelberg Akademie der Wissenschaften, Mathematisch-naturwissenschaftliche Klasse 1: $1-168$.

LinNELl J. D. C. \& STRAND O. 2000. - Interference interactions, co-existence and conservation of mammalian carnivores. Diversity and Distributions 6: 169-176. https://doi.org/10.1046/J.14724642.2000.00069.x

MAYet L. 1908. — Étude des mammiferes miocènes des Sables de l'Orléanais et des Faluns de la Touraine. Annales de l'Université de Lyon, n.s. I, Science et Médecine 24: 1-336. https://www. biodiversitylibrary.org/page/36653808

McDonald P. T., Nielsen C. K., Oyana T. J. \& Sun W. 2008. Modelling habitat overlap among sympatric mesocarnivores in southern Illinois, USA. Ecological Modelling 215: 276-286. https://doi.org/10.1016/j.ecolmodel.2008.03.021

Peigné S. 2012. - Les Carnivora de Sansan, in Peigné S. \& Sen S. (eds), Mammiferes de Sansan. Muséum National d'Histoire Naturelle, Paris: 559-660.

Peigné S., Salesa M. J., Antón M. \& Morales J. 2008. — A new amphicyonine (Carnivora: Amphicyonidae) from the upper Miocene of Batallones-1, Madrid, Spain. Palaeontology 51: 943-965. https://doi.org/10.1111/j.1475-4983.2008.00788.x

Peigné S., Salesa M. J., Antón M. \& Morales J. 2006. — New data on carnivores from the Middle Miocene (Upper Aragonian, MN 6) of Arroyo del Val area (Villafeliche, Zaragoza Province, Spain). Estudios Geológicos, 62 (1): 359-374. https:// doi.org/10.3989/egeol.0662131 
PICKFORD M. 2013. - Conohyus simorrensis (Lartet, 1851) (Suidae, Mammalia) from the Middle Miocene of Carpetana (Madrid, Spain). Spanish Journal of Palaeontology 28: 91-102.

SILICEO G. 2015. - Anatomía funcional y paleobiología de Magericyon anceps (Amphicyonidae, Carnivora) del complejo de yacimientos vallesienses (Mioceno superior, MN 10) del Cerro de los Batallones (Torrejón de Velasco, Madrid). PhD Thesis, Universidad de Alcalá, Alcalá de Henares, Madrid, Spain, 360 p.

Siliceo G., Salesa M. J., Antón, M., Pastor, J. F., \& Morales, J. 2015. - Comparative anatomy of the shoulder region in the Late Miocene amphicyonid Magericyon anceps (Carnivora): functional and paleoecological inferences. Journal of Mammalian Evolution, 22: 243-258. https://doi.org/10.1007/s10914-014-9270-9

Siliceo G., Antón M., Morales J., \& Salesa M. J. 2019. — Built for strength: functional insights from the thoracolumbar and sacrocaudal regions of the Late Miocene amphicyonid Magericyon anceps (Carnivora, Amphicyonidae) from Batallones-1 (Madrid, Spain). Journal of Mammalian Evolution: 1-22. https:// doi.org/10.1007/s10914-019-09477-6

SORKIN B. 2006. - Ecomorphology of the giant beardog Amphi- cyon and Ischyrocyon. Historical Biology 18: 375-388. https://doi. org/10.1080/08912960600618073

TAYLOR M. E. 1974. - The functional anatomy of the forelimb of some African Viverridae (Carnivora). Journal of Morphology 143 (3): 307-335. https://doi.org/10.1002/jmor.1051430305

TAYLOR M. E. 1976. - The functional anatomy of the hindlimb of some African Viverridae (Carnivora). Journal of Morphology 148: 227-253. https://doi.org/10.1002/jmor.1051480208

VirANTA S. 1996. — European Miocene Amphicyonidae - taxonomy, systematics and ecology. Acta Zoologica Fennica 204: 1-61.

WANG X. 1993. - Transformation from plantigrady to digitigrady: functional morphology of locomotion in Hesperocyon (Canidae: Carnivora). American Museum Novitates 3069: 1-23. http://hdl. handle.net/2246/4966

Werdelin L. \& Peigné S. 2010. — Carnivora, in Werdelin L. \& SANDERS W. (eds), Cenozoic mammals of Africa. University of California Press, Los Angeles: 603-657.

Werdelin L. \& Simpson S. W. 2009. — The last amphicyonid (Mammalia, Carnivora) in Africa. Geodiversitas 31: 775-787. https://doi.org/10.5252/g2009n4a775

Submitted on 31 January 2019; accepted on 19 November 2019; published on 18 June 2020. 